Check for updates

Cite this: New J. Chem., 2018, 42, 3619

Received 30th October 2017, Accepted 24th January 2018

DOI: 10.1039/c7nj04189f

rsc.li/njc

\section{Bis(picolinato) complexes of vanadium and zinc as potential antidiabetic agents: synthesis, structural elucidation and in vitro insulin-mimetic activity study $\dagger$}

\author{
Tanja Koleša-Dobravc, ${ }^{a}$ Keiichi Maejima, ${ }^{\text {b }}$ Yutaka Yoshikawa, ${ }^{c}$ Anton Meden, ${ }^{a}$ \\ Hiroyuki Yasui ${ }^{b}$ and Franc Perdih (D) *a
}

\begin{abstract}
Vanadium(v) compounds with 3,5-difluoropicolinic acid (HpicFF) and 3-hydroxypicolinic acid ( $\mathrm{H}_{2}$ hypic) and zinc(॥) compounds with $\mathrm{HpicFF}, \mathrm{H}_{2}$ hypic and 4-methylhydroxypicolinic acid $\left(\mathrm{HpicCH}_{2} \mathrm{OH}\right)$ in the presence or absence of pyridine (py), 4-(dimethylamino)pyridine (DMAP), and 1,10-phenanthroline (phen) have been synthesized and characterized. The crystal structures of $\mathrm{NH}_{4}\left[\mathrm{VO}_{2}(\text { picFF) })_{2}\right] \cdot 1.6 \mathrm{H}_{2} \mathrm{O}\left(3 \cdot 1.6 \mathrm{H}_{2} \mathrm{O}\right)$, $\mathrm{NH}_{4}\left[\mathrm{VO}_{2}(\text { hypic })_{2}\right] \cdot \mathrm{H}_{2} \mathrm{O}\left(\mathbf{4} \cdot \mathrm{H}_{2} \mathrm{O}\right),\left[\mathrm{Zn}(\text { picFF })_{2}\left(\mathrm{H}_{2} \mathrm{O}\right)_{2}\right](\mathbf{5}),\left[\mathrm{Zn}(\text { picFF })_{2}(\text { py })_{2}\right] \cdot$ py $\left(\mathbf{6} \cdot\right.$ py), $\left[\mathrm{Zn}(\text { picFF })_{2}(\mathrm{DMAP})_{2}\right] \cdot 2 / 3 \mathrm{H}_{2} \mathrm{O}$ $\left(7 \cdot 2 / 3 \mathrm{H}_{2} \mathrm{O}\right),\left[\mathrm{Zn}(\text { picFF })_{2}\right.$ (phen)].2 $\mathrm{CHCl}_{3}\left(\mathbf{8} \cdot 2 \mathrm{CHCl}_{3}\right),\left[\mathrm{Zn}(\mathrm{Hhypic})_{2}(\mathrm{MeOH})_{2}\right](\mathbf{1 0}),\left[\mathrm{Zn}(\text { Hhypic })_{2}(\mathrm{DMAP})\left(\mathrm{H}_{2} \mathrm{O}\right)\right](\mathbf{1 1})$ and $\left[\mathrm{Zn}(\mathrm{Hhypic})_{2}(\right.$ phen)] (12) were determined by X-ray crystallography. The spatial arrangement of the vanadium(v) complex 3 possesses carboxylate oxygen atoms in a mutual trans orientation while crystal structure 4 represents the first crystallographic evidence for the formation of an isomer with two picolinato nitrogen atoms in a mutual trans position. Two different spatial arrangements were found in the zinc(II) complexes with trans $(5,10$ and 11$)$ and cis $(6,7,8$ and 12) octahedral geometry. Insulin-mimetic activity of the selected $\mathrm{V}^{\mathrm{IV}} \mathrm{O}, \mathrm{V}^{\mathrm{V}} \mathrm{O}_{2}$ and $\mathrm{Zn}^{\prime \prime}$ complexes was studied by in vitro inhibition of the free fatty acid (FFA) release from isolated rat adipocytes treated with epinephrine. All the studied metal complexes showed insulin-mimetic activity. Vanadium complexes 1-4 exhibit activities similar to $\mathrm{VOSO}_{4}$ with the Hhypic complexes being more active than the picFF ones. The zinc complexes also exhibited some insulin-mimetic activity, with the Hhypic complex (9) being more active than the other two, however, the insulin-mimetic activity of these complexes did not show more potent activity than $\mathrm{ZnSO}_{4}$
\end{abstract}

\section{Introduction}

According to the estimations of the World Health Organization high blood glucose level represents a risk, that is globally the third most important factor for premature mortality, after high blood pressure and the use of tobacco. ${ }^{1}$ The worldwide number of patients suffering from diabetes mellitus (DM) has been estimated to be 415 million in 2015 representing $\sim 8.8 \%$ of

\footnotetext{
${ }^{a}$ Faculty of Chemistry and Chemical Technology, University of Ljubljana, Večna pot 113, P. O. Box 537, SI-1000 Ljubljana, Slovenia. E-mail: franc.perdih@fkkt.uni-lj.si

${ }^{b}$ Department of Analytical and Bioinorganic Chemistry, Division of Analytical and Physical Chemistry, Kyoto Pharmaceutical University, 5 Nakauchi-cho, Misasagi, Yamashina-ku, Kyoto 607-8414, Japan

${ }^{c}$ Department of Health, Sports, and Nutrition, Faculty of Health and Welfare, Kobe Women's University, 4-7-2 Minatojima-nakamachi, Chuo-ku, Kobe, 650-0046, Japan

$\dagger$ Electronic supplementary information (ESI) available. CCDC 1574080-1574088 (3-8, 10-12). For ESI and crystallographic data in CIF or other electronic format see DOI: $10.1039 / \mathrm{c} 7 \mathrm{nj} 04189 \mathrm{f}$
}

adult population and is expected to increase to 642 million by 2040 when $\sim 10 \%$ of adult population will be affected. ${ }^{1} \mathrm{DM}$ is a metabolic disorder characterized by abnormal glucose levels with a tendency to hyperglycaemia that occurs due to the decrease of insulin function and/or level. Undiagnosed hyperglycaemia represents a severe risk since it can lead to serious damage of several body systems. DM is generally classified as type 1 , type 2 , and gestational diabetes. Type $1 \mathrm{DM}$ is a consequence of an absolute lack of insulin due to autoimmune destruction of pancreatic $\beta$ cells and as such is not a lifestylerelated condition. Type $2 \mathrm{DM}$ representing the majority of diabetic patients $(\sim 90 \%)$ is caused by insulin resistance or degradation of secreted insulin and is a life-style related disease. Ageing populations and modern lifestyle, i.e. reduced physical activity, dietary changes, obesity, increasing urbanization, and increased stress are believed to be the main reason for the prevalence of DM. ${ }^{1,2}$ The treatment for type $1 \mathrm{DM}$ is subcutaneous injections of insulin, since oral administration of insulin is not efficient. Primary treatments for type $2 \mathrm{DM}$ are dietary control and regular exercise and after the development 
of the disease oral hypoglycaemic drugs are used. However, they are often associated with undesirable side effects or a drop in efficacy is observed after prolonged use $^{3}$ and patients have to start using insulin injections.

Zinc and vanadium compounds possess various biological roles in living organisms ${ }^{3-5}$ and are thus among the suitable candidates in the search for novel orally active chemotherapeutics as an alternative for the existing hypoglycaemic drugs. Zinc is essential in growth and development and plays an important role in hundreds of metalloenzymes and in thousands of metalloproteins. ${ }^{3}$ Over $75 \%$ of the zinc content in the human body is located in skeletal muscle and bone tissue. ${ }^{4}$ Zinc deficiency can lead to several diseases including diabetes and the recommended dietary allowance is $8 \mathrm{mg} \mathrm{kg}^{-1}$ for women and $11 \mathrm{mg} \mathrm{kg}^{-1}$ for men. ${ }^{4}$ Zinc compounds exhibit a wide variety of pharmacological properties, such as anticancer, ${ }^{6}$ antioxidant, ${ }^{7}$ antibacterial and antimicrobial activities, ${ }^{8}$ as well as effects in the treatment of Alzheimer disease. ${ }^{9}$ Biological activities of vanadium compounds, e.g., as antitumor, antiparasitic (Chagas disease), and osteogenic agents have also been described. ${ }^{10}$ The first report regarding the influence of vanadium on diabetic patients dates back to 1899 when Lyonett and Martin observed reduced levels of glucose in the urine of patients using sodium metavanadate. ${ }^{11,12}$ In 1980 and in 1992 it was found that vanadium and zinc salts, respectively, mimic the action of insulin. ${ }^{3,12}$ Those findings gave impetus to the extensive research on zinc and vanadium coordination compounds where organic carriers were found to substantially increase the bioavailability and reduce the administrated doses needed. ${ }^{13}$ Several classes of very promising complexes consist of $\mathrm{Zn}$ and $\mathrm{V}$ species among which the ethylmaltolato vanadium complex has entered the phase IIa clinical trials. Further studies on this compound as an antidiabetic agent were abandoned due to renal problems, however, it is currently studied as a therapeutic for the prevention, stoppage, and reparation of secondary tissue injuries. ${ }^{13 f}$ Picolinato complexes were also found to possess strong antidiabetic action. Several derivatives of the picolinato scaffold have been prepared, such as 6-methylpicolinate, 6-ethylpicolinate, halopicolinates, 3-hydroxypicolinate, and also species formed by monoesters and amides of 2,5-dipicolinic acid, all exhibiting insulin-mimetic properties. $^{3,14}$ Additionally, complexes with several other ligand systems have been studied during the last few years ${ }^{15}$ among which complexes with antioxidants such as allixin, $S$-allixin- $N$ methyl and pyrrolidine- $N$-dithiocarbamato ligands were found to be particularly active. ${ }^{16}$ All these recent efforts have been oriented towards the synthesis of new compounds with high bioavailability and low toxicity since the main obstacle with the ethylmaltolato vanadium complex was the high dose necessary to achieve the therapeutic effect. ${ }^{13 f}$ Recently it has been established on selected zinc complexes by noninvasive methods for analyzing the biodistribution of complexes that high antidiabetic activity correlates with a long retention time of complexes in the blood..$^{17}$ According to Rehder, ${ }^{10 a}$ ligands containing the pyrone, the pyridinone or the pyridine-carboxylate scaffold are seen as the best candidates with a sufficiently long physiological half-life to recombine with metal in the body and thus to decrease potential toxicity.

Herein, we report ten vanadium and zinc compounds formed by 3,5-difluoropicolinic acid (HpicFF), 3-hydroxypicolinic acid $\left(\mathrm{H}_{2}\right.$ hypic) and 4-(hydroxymethyl)picolinic acid $\left(\mathrm{HpicCH}_{2} \mathrm{OH}\right)$. Structural characterization of nine complexes was carried out by $\mathrm{X}$-ray diffraction analysis. Insulin-mimetic activity of the selected complexes was studied by an in vitro inhibition of the FFA release from isolated rat adipocytes treated with epinephrine.

\section{Experimental section}

\section{Materials and physical measurements}

Reagents and solvents were used as received from commercial suppliers. Oxidovanadium(Iv), $\mathrm{V}^{\mathrm{IV}} \mathrm{O}$, compounds [VO(picFF $)_{2}\left(\mathrm{H}_{2} \mathrm{O}\right)$ ] (1) and $\mathrm{Na}\left[\mathrm{VO}(\text { Hhypic })_{3}\right] \cdot \mathrm{H}_{2} \mathrm{O}(2)$ were synthesized from $\mathrm{VOSO}_{4} \cdot 5 \mathrm{H}_{2} \mathrm{O}$ and HpicFF or $\mathrm{H}_{2}$ hypic as described previously. ${ }^{18}$ Compound $\left[\mathrm{Zn}(\text { Hhypic })_{2}\left(\mathrm{H}_{2} \mathrm{O}\right)_{2}\right]$ (9) was prepared by a modified synthetic procedure. ${ }^{19}$ Infrared (IR) spectra $\left(4000-600 \mathrm{~cm}^{-1}\right)$ of the samples were recorded using a Perkin-Elmer Spectrum 100, equipped with a Specac Golden Gate Diamond ATR as a solid sample support. Elemental (C, H, N) analyses were obtained using a Perkin-Elmer 2400 Series II CHNS/O Elemental Analyser.

\section{Synthesis}

Ammonium bis(3,5-difluoropicolinato- $\left.\kappa^{2} \mathrm{~N}, \mathrm{O}\right)$ dioxidovanadate(v)water (1/1.6) $\left(3 \cdot 1.6 \mathbf{H}_{2} \mathbf{O}\right)$. Ammonium metavanadate $(58 \mathrm{mg}$, $0.50 \mathrm{mmol}$ ) was suspended in methanol $(2 \mathrm{~mL})$ and a solution of HpicFF (159 mg, $1.00 \mathrm{mmol}$ ) in methanol (5 mL) was added. The resulting solution was stirred at room temperature for $30 \mathrm{~min}$ until dissolution and the solution turned light green. The solution obtained after filtration was stored at room temperature. After a few days of slow evaporation of the solvent, light green crystals grew from the solution. Yield: $127 \mathrm{mg}, 57 \%$. Anal. calcd for $\left(\mathrm{C}_{12} \mathrm{H}_{11.2} \mathrm{~F}_{4} \mathrm{~N}_{3} \mathrm{O}_{7.6} \mathrm{~V}\right)$ : C, 32.32; H, 2.53; N, 9.42. Found: C, 32.05; $\mathrm{H}, 2.64 ; \mathrm{N}, 9.02 \%$. IR (ATR, $\mathrm{cm}^{-1}$ ): 3445br, 3176w, 3052m, $1666 \mathrm{~s}, 1600 \mathrm{~m}, 1472 \mathrm{~m}, 1429 \mathrm{~m}, 1330 \mathrm{~s}, 1245 \mathrm{~s}, 1213 \mathrm{w}, 1157 \mathrm{w}$, $1118 \mathrm{~s}, 1000 \mathrm{w}, 891 \mathrm{~s}, 853 \mathrm{~m}, 681 \mathrm{~m}, 633 \mathrm{~m}$.

Ammonium bis(3-hydroxypicolinato- $\left.\kappa^{2} \mathrm{~N}, \mathrm{O}\right)$ dioxidovanadate(v) hydrate $\left(4 \cdot \mathbf{H}_{2} \mathbf{O}\right)$. Ammonium metavanadate $(58 \mathrm{mg}, 0.50 \mathrm{mmol})$ was suspended in water $(5 \mathrm{~mL})$ and a solution of $\mathrm{H}_{2}$ hypic $(139 \mathrm{mg}$, $1.00 \mathrm{mmol})$ in methanol $(3 \mathrm{~mL})$ was added. The resulting solution was stirred under reflux until dissolution $(\sim 15 \mathrm{~min})$. The solution obtained after hot filtration was stored at room temperature. After a few days of the slow evaporation of solvents, yellow-green crystals grew from the solution. Yield: $98 \mathrm{mg}, 50 \%$. Anal. calcd for $\left(\mathrm{C}_{12} \mathrm{H}_{14} \mathrm{~N}_{3} \mathrm{O}_{9} \mathrm{~V}\right)$ : C, 36.47; H, 3.57; N, 10.63. Found: C, 36.40; $\mathrm{H}, 3.48$; N, 10.51\%. IR (ATR, $\mathrm{cm}^{-1}$ ): 3504br, 3260br, 3072br, $1637 \mathrm{~m}, 1606 \mathrm{~m}, 1571 \mathrm{w}, 1457 \mathrm{~m}, 1400 \mathrm{~m}, 1312 \mathrm{~s}, 1261 \mathrm{w}, 1230 \mathrm{w}$, $1156 \mathrm{w}, 1125 \mathrm{w}, 897 \mathrm{~m}, 869 \mathrm{~s}, 822 \mathrm{~m}, 782 \mathrm{w}, 689 \mathrm{~s}$.

trans-Di(aqua-кO)bis(3,5-difluoropicolinato- $\kappa^{2} N, O$ )zinc(II) (5). Zinc acetate dihydrate $(110 \mathrm{mg}, 0.50 \mathrm{mmol})$ was dissolved in water $(2 \mathrm{~mL})$ and a hot solution of HpicFF (159 mg, $1.00 \mathrm{mmol}$ ) in methanol $(6 \mathrm{~mL})$ was added. After the addition, a white precipitate was found in the mixture. The resulting suspension 
was stirred at $60{ }^{\circ} \mathrm{C}$ for an additional $30 \mathrm{~min}$ and then cooled to room temperature. The white precipitate was filtered, washed with methanol and dried on air. Yield: $185 \mathrm{mg}, 97 \%$. Anal. calcd for $\left(\mathrm{C}_{12} \mathrm{H}_{8} \mathrm{~F}_{4} \mathrm{~N}_{2} \mathrm{O}_{6} \mathrm{Zn}\right)$ : C, 34.52; $\mathrm{H}, 1.93 ; \mathrm{N}, 6.71$. Found: $\mathrm{C}, 34.53$; $\mathrm{H}, 1.71 ; \mathrm{N}, 6.63 \%$. IR (ATR, $\mathrm{cm}^{-1}$ ): 3385m, 3078m, 1636s, $1604 \mathrm{~m}, 1590 \mathrm{w}, 1470 \mathrm{w}, 1422 \mathrm{w}, 1379 \mathrm{~s}, 1362 \mathrm{~m}, 1318 \mathrm{~m}, 1255 \mathrm{~m}$, $1223 \mathrm{~m}, 1154 \mathrm{w}, 1126 \mathrm{~m}, 999 \mathrm{~m}, 905 \mathrm{~m}, 845 \mathrm{~m}, 746 \mathrm{~m}, 678 \mathrm{~s}, 620 \mathrm{~s}$.

cis-Bis(3,5-difluoropicolinato- $\left.\kappa^{2} N, O\right) \operatorname{di}($ pyridine- $\kappa N)$ zinc(II)pyridine (1/1) (6-py). Compound $5(21 \mathrm{mg}, 0.050 \mathrm{mmol})$ was dissolved in a mixture of toluene $(3 \mathrm{~mL})$, methanol $(1 \mathrm{~mL})$ and pyridine ( $2 \mathrm{~mL}, 25 \mathrm{mmol})$. The resulting solution was stirred under reflux for $30 \mathrm{~min}$, then hot filtered and stored at room temperature. After few days of slow evaporation of solvents, colorless crystals grew from the solution. The crystals decomposed when exposed to air. Elemental analysis shows that the pyridine moiety leaves the complex and crystal lattice outside the solution, while it is replaced by water molecules. Yield: $17 \mathrm{mg}, 55 \%$. Anal. calcd for diaqua complex $\left(\mathrm{C}_{12} \mathrm{H}_{8} \mathrm{~F}_{4} \mathrm{~N}_{2} \mathrm{O}_{6} \mathrm{Zn}\right)$ : C, 34.52; $\mathrm{H}, 1.93$; $\mathrm{N}, 6.71$. Found: C, 35.08; H, 2.06; N, 6.80\%. IR (ATR, $\mathrm{cm}^{-1}$ ): 3062w, $1654 \mathrm{~s}, 1599 \mathrm{~m}, 1466 \mathrm{~m}, 1445 \mathrm{~m}, 1420 \mathrm{~m}, 1346 \mathrm{~s}, 1250 \mathrm{~s}, 1221 \mathrm{w}, 1120 \mathrm{~s}$, 1040w, 999w, 904w, 830m, 768w, 698m, 686m, 617s.

cis-Bis(3,5-difluoropicolinato- $\left.\kappa^{2} \mathrm{~N}, \mathrm{O}\right) \mathrm{bis}(4$-dimethylaminopyridine-кN)zinc(II)-water $(3 / 2) \quad\left(7 \cdot 2 / 3 \mathbf{H}_{2} \mathrm{O}\right)$. Compound 5 (21 $\mathrm{mg}, 0.050 \mathrm{mmol}$ ) was suspended in toluene $(5 \mathrm{~mL})$ and a solution of DMAP (12 $\mathrm{mg}, 0.10 \mathrm{mmol})$ in methanol $(3 \mathrm{~mL})$ was added. The resulting solution was stirred for $120 \mathrm{~min}$ at $70{ }^{\circ} \mathrm{C}$. The solution obtained after hot filtration was stored at room temperature. After a few days of slow evaporation of solvents, colorless crystals grew from the solution. Yield: $12 \mathrm{mg}, 37 \%$. Anal. calcd for $\left(\mathrm{C}_{26} \mathrm{H}_{25.33} \mathrm{~F}_{4} \mathrm{~N}_{6} \mathrm{O}_{4.66} \mathrm{Zn}\right): \mathrm{C}, 48.96$; $\mathrm{H}, 4.00 ; \mathrm{N}, 13.18$. Found: C, 48.95; H, 3.70; N, 12.92\%. IR (ATR, $\mathrm{cm}^{-1}$ ): 3061w, 1646s, 1613s, 1536m, 1463w, 1419w, 1346s, $1249 \mathrm{~m}, 1228 \mathrm{~s}, 1118 \mathrm{~m}, 1010 \mathrm{~s}, 902 \mathrm{w}, 827 \mathrm{~m}, 811 \mathrm{~m}, 687 \mathrm{~m}, 614 \mathrm{~s}$.

$\operatorname{Bis}\left(3,5\right.$-difluoropicolinato- $\left.\kappa^{2} N, O\right)\left(1,10-\right.$ phenanthroline- $\left.\kappa^{2} N, N^{\prime}\right)$ zinc(II)-chloroform (1/2) (8.2CHCl $\left.\mathbf{H}_{3}\right)$. Compound $5(21 \mathrm{mg}$, $0.05 \mathrm{mmol})$ was suspended in chloroform $(4 \mathrm{~mL})$ and then solid 1,10-phenanthroline (9 $\mathrm{mg}, 0.05 \mathrm{mmol}$ ) was added. Methanol $(2 \mathrm{~mL})$ was added and the resulting mixture was stirred under reflux for $15 \mathrm{~min}$. The solution obtained after hot filtration was stored at room temperature. After few days of the slow evaporation of solvents colorless crystals grew from the solution. The crystals decomposed in air, elemental analysis showed that the chloroform solvate molecules leave the crystal lattice when the crystals are dried in air. Yield: $15 \mathrm{mg}, 51 \%$. Anal. calcd for $\left(\mathrm{C}_{25} \mathrm{H}_{16} \mathrm{~F}_{4} \mathrm{~N}_{4} \mathrm{O}_{5} \mathrm{Zn}\right)$ : C, 50.57; $\mathrm{H}, 2.72$; $\mathrm{N}, 9.44$; found: C, 50.99; H, 2.91; N, 9.20\%. IR (ATR, $\mathrm{cm}^{-1}$ ): $3359 \mathrm{w}, 3063 \mathrm{w}, 1648 \mathrm{~s}, 1636 \mathrm{~m}, 1601 \mathrm{w}, 1521 \mathrm{w}, 1465 \mathrm{~m}, 1421 \mathrm{~m}$, $1356 \mathrm{~m}, 1337 \mathrm{~m}, 1253 \mathrm{~s}, 1119 \mathrm{~s}, 1007 \mathrm{~m}, 898 \mathrm{w}, 848 \mathrm{~m}, 833 \mathrm{w}, 726 \mathrm{~s}$, $686 \mathrm{~m}, 616 \mathrm{~s}$.

trans-Di(aqua-кO)bis(3-hydroxypicolinato- $\kappa^{2} N, O$ )zinc(II) (9). Zinc acetate dihydrate $(110 \mathrm{mg}, 0.50 \mathrm{mmol})$ was dissolved in water $(2 \mathrm{~mL})$ and a hot solution of $\mathrm{H}_{2}$ hypic $(139 \mathrm{mg}, 1.00 \mathrm{mmol}$ ) in water $(3 \mathrm{~mL})$ was added. After the addition, a white precipitate occurred in the mixture. The resulting suspension was stirred under reflux for $20 \mathrm{~min}$ and then cooled to room temperature. The white precipitate was filtered, washed with methanol and dried in air. Yield: $181 \mathrm{mg}, 96 \%$. Anal. calcd for $\left(\mathrm{C}_{12} \mathrm{H}_{12} \mathrm{~N}_{2} \mathrm{O}_{8} \mathrm{Zn}\right)$ : C, 38.17; H, 3.20; N, 7.42. Found: C, 38.28; $\mathrm{H}, 2.87$; N, 7.46\%. IR (ATR, $\mathrm{cm}^{-1}$ ): 3282m, 1650m, 1576w, $1450 \mathrm{~s}, 1405 \mathrm{~m}, 1392 \mathrm{~m}, 1341 \mathrm{~m}, 1300 \mathrm{~s}, 1231 \mathrm{~m}, 1139 \mathrm{w}, 1117 \mathrm{~m}$, 892m, 842m, 803s, 689s.

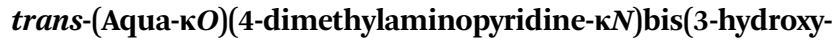
picolinato- $\kappa^{2} \boldsymbol{N}, O$ )zinc(II) dihydrate (11). Compound $9(38 \mathrm{mg}$, $0.10 \mathrm{mmol})$ was suspended in toluene $(5 \mathrm{~mL})$ and a solution of DMAP (24 mg, $0.20 \mathrm{mmol}$ ) in chloroform (3 mL) was added. Methanol (3 mL) was added and the resulting mixture was stirred for $10 \mathrm{~min}$ at $50{ }^{\circ} \mathrm{C}$. The solution obtained after hot filtration was stored at room temperature. After a few days of slow evaporation of solvents, colorless crystals grew from the solution. Yield: $43 \mathrm{mg}, 90 \%$. Anal. calcd for $\left(\mathrm{C}_{19} \mathrm{H}_{20} \mathrm{~N}_{4} \mathrm{O}_{7} \mathrm{Zn}\right)$ : C, 47.37; H, 4.18; N, 11.63. Found: C, 47.12; H, 4.02; N, 11.88\%. IR (ATR, cm ${ }^{-1}$ ): 3318w, 2901w, 1618s, 154w, 1453s, $1388 \mathrm{~m}$, $1330 \mathrm{~m}, 1303 \mathrm{~m}, 1241 \mathrm{~m}, 1223 \mathrm{~s}, 1114 \mathrm{w}, 1059 \mathrm{~m}, 1009 \mathrm{~m}, 887 \mathrm{~m}$, $846 \mathrm{~m}, 807 \mathrm{~s}, 700 \mathrm{~m}, 682 \mathrm{~s}$.

Bis(3-hydroxypicolinato- $\left.\kappa^{2} N, O\right)\left(1,10\right.$-phenanthroline- $\left.\kappa^{2} N, N^{\prime}\right)$ zinc(II) (12). Compound 9 (38 $\mathrm{mg}, 0.10 \mathrm{mmol}$ ) was suspended in toluene $(5 \mathrm{~mL})$ and a solution of phen $(9 \mathrm{mg}, 0.10 \mathrm{mmol})$ in methanol $(5 \mathrm{~mL})$ was added. The resulting solution was stirred for $10 \mathrm{~min}$ at $50{ }^{\circ} \mathrm{C}$. The solution obtained after hot filtration was stored at room temperature. After a few days of slow evaporation of solvents, colorless crystals grew from the solution. Yield $32 \mathrm{mg}, 61 \%$. Anal. calcd for $\left(\mathrm{C}_{24} \mathrm{H}_{16} \mathrm{~N}_{4} \mathrm{O}_{6} \mathrm{Zn}\right): \mathrm{C}$, 55.24; H, 3.09; N, 10.74. Found: C, 55.34; H, 2.94; N, 10.74\%. IR (ATR, cm ${ }^{-1}$ ): 3060w, 1636s, 1594w, 1455s, 1428w, 1382m, $1336 \mathrm{~m}, 1304 \mathrm{~m}, 1249 \mathrm{~m}, 1227 \mathrm{w}, 1146 \mathrm{w}, 883 \mathrm{~m}, 852 \mathrm{~m}, 813 \mathrm{~s}, 725 \mathrm{~m}$, 699m, 680s, 638w.

Bis(4-(hydroxymethyl)picolinato- $\left.\kappa^{2} N, O\right)$ zinc(II)-water (1/0.5) (13.0.5 $\left.\mathrm{H}_{2} \mathrm{O}\right)$. Zinc acetate dihydrate $(110 \mathrm{mg}, 0.50 \mathrm{mmol})$ was dissolved in methanol $(2 \mathrm{~mL})$ and a hot solution of $\mathrm{HpicCH}_{2} \mathrm{OH}$ $(153 \mathrm{mg}, 1.00 \mathrm{mmol})$ in methanol $(6 \mathrm{~mL})$ was added. After the addition, a white precipitate was found in the mixture. The resulting suspension was stirred under reflux for $20 \mathrm{~min}$ and then cooled to room temperature. The white precipitate was filtered, washed with methanol and dried in air. Yield: $148 \mathrm{mg}$, $80 \%$. Anal. calcd for $\left(\mathrm{C}_{14} \mathrm{H}_{13} \mathrm{~N}_{2} \mathrm{O}_{6.5} \mathrm{Zn}\right)$ : C, 44.41; H, 3.46; N, 7.40. Found: C, 44.23; H, 3.00; N, 7.21\%. IR (ATR, $\mathrm{cm}^{-1}$ ): 3033br, $2635 \mathrm{br}, 1629 \mathrm{w}, 1598 \mathrm{~s}, 1559 \mathrm{w}, 1436 \mathrm{~m}, 1376 \mathrm{~s}, 1331 \mathrm{w}, 1286 \mathrm{w}$, $1233 \mathrm{w}, 1065 \mathrm{~m}, 1025 \mathrm{~m}, 859 \mathrm{w}, 801 \mathrm{~m}, 701 \mathrm{~m}, 627 \mathrm{~m}$.

\section{$\mathrm{X}$-ray structure determination}

Crystals suitable for X-ray analysis were obtained from compound solutions or filtered reaction mixtures at room temperature by slow evaporation of the solvents over a few days. Single-crystal $\mathrm{X}$-ray diffraction data were collected on either a Nonius Kappa CCD diffractometer or an Agilent Technologies SuperNova Dual diffractometer with an Atlas detector using monochromated Mo-K $\alpha$ radiation $(\lambda=0.71073 \AA$ ) or $\mathrm{Cu}-\mathrm{K} \alpha$ radiation $(\lambda=1.54184 \AA)$ at room temperature or at $150 \mathrm{~K}$. The data were processed using DENZO or CrysAlis Pro. ${ }^{20}$ The structures were solved by direct methods using the program SHELXS-97 or SIR97 and refined on $F^{2}$ using full-matrix least-squares procedures with SHELX2014. ${ }^{21}$ All non-hydrogen atoms were refined anisotropically. The 
hydrogen atoms on carbon atoms and $\mathrm{OH}$ groups were treated as riding atoms in geometrically idealized positions. Hydrogen atoms attached to the nitrogen atom of ammonium cations, water and methanol oxygen atoms were readily located from difference Fourier maps and were refined fixing the bond lengths and isotropic temperature factors as $U_{\text {iso }}(\mathrm{H})=1.5 U_{\text {eq }}(\mathrm{N}, \mathrm{O})$ unless otherwise noted. In $3 \cdot 1.6 \mathrm{H}_{2} \mathrm{O}$ water oxygen atoms $\mathrm{O} 8$, $\mathrm{O} 9$ and O10 were refined with a $0.25: 0.20: 0.14$ occupancy ratio and ISOR instruction was used on them for proper refinement. Hydrogen atoms on the $\mathrm{O} 7-\mathrm{O} 10$ atoms in $\mathbf{3} \cdot 1 \cdot 6 \mathrm{H}_{2} \mathrm{O}$ and on the $\mathrm{O} 13$ and $\mathrm{O} 14$ atoms in $7 \cdot 2 / 3 \mathrm{H}_{2} \mathrm{O}$ were not found in the difference Fourier maps and were not included in the refinement. In $8 \cdot 2 \mathrm{CHCl}_{3}$ the chloroform solvate molecule is disordered over two positions in a refined ratio of $0.60: 0.40$, and DFIX, SADI, SIMU and DELU instructions were used on the solvate molecule for the appropriate refinement. Crystallographic data are listed in Table S1 (ESI $\dagger$ ).

\section{In vitro insulin-mimetic activity}

The procedure for the in vitro test was adopted from the literature. ${ }^{22}$ Male Wistar rats were sacrificed under anesthesia with ether. The adipose tissues were removed, chopped with scissors, and digested with collagenase for $60 \mathrm{~min}$ at $37^{\circ} \mathrm{C}$ in Krebs-Ringer bicarbonate buffer $\left(120 \mathrm{mM} \mathrm{NaCl}, 1.27 \mathrm{mM} \mathrm{CaCl}_{2}\right.$, $1.2 \mathrm{mM} \mathrm{MgSO}_{4}, 4.75 \mathrm{mM} \mathrm{KCl}, 1.2 \mathrm{mM} \mathrm{KH}_{2} \mathrm{PO}_{4}, 24 \mathrm{mM} \mathrm{NaHCO}_{3}$ : $\mathrm{pH} 7.4$ ), containing $2 \%$ BSA (bovine serum albumin). The obtained adipocytes were then separated from undigested tissues by filtration through nylon mesh and washed three times. The metal complexes which were dissolved in ultrapure water at $500 \mu \mathrm{M}$ (final conc.) and glucose solution (final conc.; $5 \mathrm{mM}$ ) was separately added to the isolated adipocytes, and the resulting suspension was pre-incubated at $37{ }^{\circ} \mathrm{C}$ for $30 \mathrm{~min}$. Finally, epinephrine solution (final conc.; $10 \mu \mathrm{M}$ ) was added to the above suspension, and the resulting solutions were incubated at $37{ }^{\circ} \mathrm{C}$ for $180 \mathrm{~min}$. The reactions were stopped by soaking in ice water, and the mixtures were centrifuged at $3000 \mathrm{rpm}$ for $10 \mathrm{~min}$. FFA (free fatty acids) levels in the outer solution of the cells were determined using an FFA kit (NEFA C-test WAKO, Wako Pure Chemicals).

All animal experiments in the present study were approved by the Experimental Animal Research of Kyoto Pharmaceutical University (KPU) and were performed according to the Guideline for Animal Experimentation of KPU.

\section{Results and discussion}

\section{Synthesis and IR spectroscopy}

Oxidovanadium(Iv), $\mathrm{V}^{\mathrm{IV}} \mathrm{O}$, compounds 1 and $\mathbf{2}$ were synthesized from VOSO $_{4} \cdot 5 \mathrm{H}_{2} \mathrm{O}$ and HpicFF or $\mathrm{H}_{2}$ hypic as described previously. ${ }^{18}$ Dioxidovanadate(v) and $\mathrm{V}^{\mathrm{V}} \mathrm{O}_{2}$, compounds were prepared from ammonium metavanadate and the corresponding picolinic acid analogues, HpicFF (3) or $\mathrm{H}_{2}$ hypic (4), in a $1: 2$ ratio in methanol or water/methanol, respectively.

Zinc(II) bis(3,5-difluoropicolinato) and bis(3-hydroxypicolinato) complexes were prepared in two steps. In the first step the white powder of the zinc bis(3,5-difluoropicolinato) compound
(5) and the zinc bis(3-hydroxypicolinato) compound (9) were prepared in a water/methanol mixture or in water from zinc acetate dihydrate and HpicFF or $\mathrm{H}_{2}$ hypic acid in a $1: 2$ ratio. In the second step 5 or $\mathbf{9}$ was suspended in an organic solvent and then the neutral N-donor ligands py (6-py), DMAP $\left(7 \cdot 2 / 3 \mathrm{H}_{2} \mathrm{O}, 11\right)$ or phen $\left(\mathbf{8} \cdot \mathrm{CHCl}_{3}, \mathbf{1 2}\right)$ were added. The $\mathrm{N}$-donor ligands were selected in order to make a structural comparison with previously published zinc complexes with the 5-cyanopicolinato (picCN) organic carrier where a cis-octahedral arrangement was observed in py and 4-aminopyridine (4apy) complexes and also a square-pyramidal geometry was observed in the 4apy complex in contrast to the $\left[\mathrm{Zn}(\text { picCN })_{2}\left(\mathrm{H}_{2} \mathrm{O}\right)_{2}\right]$ complex possessing a trans arrangement of the ligands in the coordination sphere. ${ }^{23}$ The reaction of 5 with py in toluene/methanol yielded crystals 6.py, however, when these crystals were dried in air, the pyridine was lost and the complex decomposed transforming into the compound $\mathbf{5}$ as was observed also in the analogous system with the picCN ligand. ${ }^{23}$ The reaction of 9 with DMAP yielded complex 11 even though the ratio $1: 2$ was used. A small amount of crystals of 10 with methanol molecules bonded to the metal center were obtained during the unsuccessful synthesis of $\mathbf{1 1}$ in methanol. For comparison, the reaction of $\left[\mathrm{Zn}(\text { picCN })_{2}\left(\mathrm{H}_{2} \mathrm{O}\right)_{2}\right]$ with py in methanol yielded only the starting complex, the substitution of the water by py or $\mathrm{MeOH}$ as the ligand was not observed. ${ }^{23}$ The zinc bis(4-(hydroxymethyl)picolinato) compound $13 \cdot 0.5 \mathrm{H}_{2} \mathrm{O}$ was prepared in methanol in an analogous way as were compounds 5 and 9. Although several attempts were made to structurally characterize the zinc bis(4-(hydroxymethyl)picolinato) species in the presence or absence of neutral N-donors we were not able

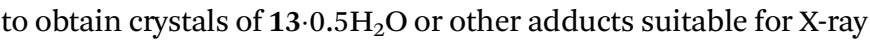
structural determination.

IR spectroscopy of $\mathbf{3}$ and $\mathbf{4}$ shows the presence of $\mathrm{N}-\mathrm{H}$ stretching vibrations of the ammonium cation in the range between 3176 and $3052 \mathrm{~cm}^{-1}$ in both compounds and stretching bands of the $\mathrm{VO}_{2}{ }^{+}$cation were observed between 897 and $853 \mathrm{~cm}^{-1}$. The IR spectra of vanadium compounds 3 and 4 and zinc compounds 5-9 and 11-13 show antisymmetric, $\nu_{\text {asym }}\left(\mathrm{CO}_{2}\right)$, and symmetric, $\nu_{\text {sym }}\left(\mathrm{CO}_{2}\right)$, stretching vibrations of the carboxylato group in the ranges of $1666-1598 \mathrm{~cm}^{-1}$ and $1392-1300 \mathrm{~cm}^{-1}$, respectively. The difference $\Delta$, a useful parameter revealing the possible coordination mode of the carboxylato ligands, has values greater than $200 \mathrm{~cm}^{-1}$ for each of these complexes indicating a monodentate coordination of the carboxylate group. ${ }^{24}$

\section{Structure of the complexes}

Crystal structures of $\mathrm{NH}_{4}\left[\mathrm{VO}_{2}(\text { picFF })_{2}\right] \cdot 1.6 \mathrm{H}_{2} \mathrm{O}\left(3 \cdot 1.6 \mathrm{H}_{2} \mathrm{O}\right)$ and $\mathrm{NH}_{4}\left[\mathrm{VO}_{2}(\text { Hhypic })_{2}\right] \cdot \mathrm{H}_{2} \mathrm{O}\left(\mathbf{4} \cdot \mathrm{H}_{2} \mathrm{O}\right)$. Crystals of compounds $\mathbf{3}$ and $\mathbf{4}$ were grown from the reaction mixtures after a few days of slow evaporation of the solvents. Diagrams of the structures of both complexes are shown in Fig. 1 and 3, and selected bond distances and angles are summarized in Tables 1 and 2 . Compound $3 \cdot 1.6 \mathrm{H}_{2} \mathrm{O}$ crystallizes in the tetragonal space group $\mathrm{P}_{2} / n$ and the asymmetric unit contains a complex dioxidovanadate(v) anion, an ammonium cation, one water molecule with full occupancy and 0.6 water molecule disordered over three 


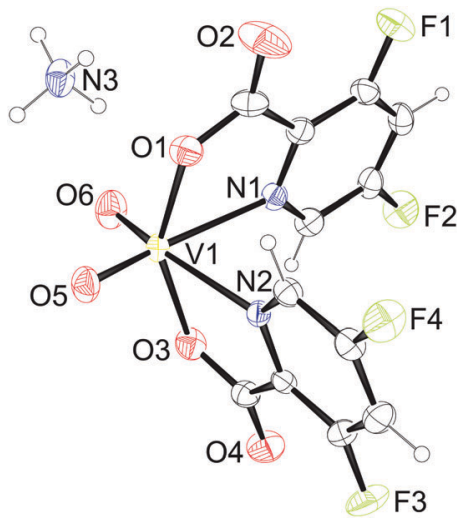

Fig. 1 Structure of $\mathrm{NH}_{4}\left[\mathrm{VO}_{2}(\text { picFF })_{2}\right] \cdot 1.6 \mathrm{H}_{2} \mathrm{O}\left(3 \cdot 1.6 \mathrm{H}_{2} \mathrm{O}\right)$. Thermal ellipsoids are shown with $30 \%$ probability level at $293 \mathrm{~K}$. Crystal water molecules have been omitted for clarity.

Table 1 Selected bond distances $(\AA)$ and angles $\left({ }^{\circ}\right)$ for $\mathrm{NH}_{4}\left[\mathrm{VO}_{2}(\text { picFF })_{2}\right]$. $1.6 \mathrm{H}_{2} \mathrm{O}\left(3 \cdot 1.6 \mathrm{H}_{2} \mathrm{O}\right)$

\begin{tabular}{llll}
\hline Distance $(\AA)$ & & & \\
\hline V1-O1 & $1.964(4)$ & V1-O6 & $1.629(4)$ \\
V1-O3 & $1.988(4)$ & V1-N1 & $2.332(5)$ \\
V1-O5 & $1.628(4)$ & V1-N2 & $2.322(4)$ \\
\hline Angle $\left(^{\circ}\right)$ & & & \\
\hline O1-V1-O3 & $149.82(18)$ & O3-V1-N2 & $72.38(15)$ \\
O1-V1-O5 & $97.4(2)$ & O5-V1-O6 & $105.2(2)$ \\
O1-V1-O6 & $103.1(2)$ & O5-V1-N1 & $165.0(2)$ \\
O1-V1-N1 & $73.11(16)$ & O5-V1-N2 & $89.93(19)$ \\
O1-V1-N2 & $83.97(16)$ & O6-V1-N1 & $88.5(2)$ \\
O3-V1-O5 & $100.9(2)$ & O6-V1-N2 & $162.1(2)$ \\
O3-V1-O6 & $95.0(2)$ & N1-V1-N2 & $77.74(16)$ \\
O3-V1-N1 & $83.55(17)$ & & \\
\hline
\end{tabular}

Table 2 Selected bond distances $(\AA)$ and angles $\left(^{\circ}\right)$ for $\mathrm{NH}_{4}\left[\mathrm{VO}_{2}(\text { Hhypic })_{2}\right]$. $\mathrm{H}_{2} \mathrm{O}\left(4 \cdot \mathrm{H}_{2} \mathrm{O}\right)$

\begin{tabular}{llll}
\hline Distance $(\AA)$ & & & \\
\hline $\mathrm{V} 1-\mathrm{O} 1$ & $2.149(4)$ & $\mathrm{V} 1-\mathrm{N} 1$ & $2.116(4)$ \\
$\mathrm{V} 1-\mathrm{O} 4$ & $1.624(3)$ & & \\
\hline Angle $\left(^{\circ}\right)$ & & & \\
\hline $\mathrm{O} 1-\mathrm{V} 1-\mathrm{O} 1^{\mathrm{i}}$ & $76.7(2)$ & $\mathrm{O} 4-\mathrm{V} 1-\mathrm{O} 4^{\mathrm{i}}$ & $104.1(3)$ \\
$\mathrm{O} 1-\mathrm{V} 1-\mathrm{O} 4$ & $91.00(16)$ & $\mathrm{O} 4-\mathrm{V} 1-\mathrm{N} 1$ & $100.36(16)$ \\
$\mathrm{O} 1-\mathrm{V} 1-\mathrm{O} 4^{\mathrm{i}}$ & $161.15(16)$ & $\mathrm{O} 4-\mathrm{V} 1-\mathrm{N} 1^{\mathrm{i}}$ & $90.51(16)$ \\
$\mathrm{O}^{\mathrm{i}}-\mathrm{V} 1-\mathrm{N} 1$ & $75.55(14)$ & $\mathrm{N} 1-\mathrm{V} 1-\mathrm{N} 1^{\mathrm{i}}$ & $162.3(2)$ \\
$\mathrm{O} 1-\mathrm{V} 1-\mathrm{N} 1^{\mathrm{i}}$ & $90.50(15)$ & &
\end{tabular}

Symmetry code: (i) $-x+1, y,-z+1 / 2$.

positions. Compound 4 crystallizes in the monoclinic space group $C 2 / c$ and the asymmetric unit contains one half of the complex anion, one half of the ammonium cation and one half of the water molecule due to the two-fold rotation axis.

Vanadium atom in $\mathbf{3}$ is six-coordinated having an octahedral geometry with a cis arrangement of oxido oxygen atoms of the $\mathrm{VO}_{2}^{+}$group and two bidentate 3,5-difluoropicolinate (picFF) ligands coordinated with picolinato nitrogen atoms trans to oxido oxygen atoms $[\mathrm{V}-\mathrm{N}=2.332(5)$ and $2.322(4) \AA]$ and carboxylate oxygen atoms in mutual trans orientation $[\mathrm{V}-\mathrm{O}=1.964(4)$ and 1.988(4) $\AA$ ] . The octahedral geometry displays a distortion with O5-V1-N1 and O6-V1-N2 angles of 165.0(2) and 162.1(2) respectively, and an O1-V1-O3 angle of $149.82(18)^{\circ}$.

Ammonium cations and complex anions in the crystal structure of $3 \cdot 1.6 \mathrm{H}_{2} \mathrm{O}$ are connected into the infinite belt along the $c$ axis. The ammonium cation is connected to three adjacent $\left[\mathrm{VO}_{2}(\mathrm{picFF})_{2}\right]^{-}$complex anions where the hydrogenbond acceptors are the $\mathrm{O} 1$ carboxyl atom of one complex anion, the $\mathrm{O} 3$ carboxyl atom of the second complex anion and the $\mathrm{O} 5$ oxido oxygen atom of the $\mathrm{VO}_{2}{ }^{+}$unit of the third complex anion. The fourth hydrogen-bonding of ammonium cation is with the $\mathrm{O} 7$ atom of the water molecule (Fig. S1 and Table S2, ESI $\dagger$ ). Additionally, $\mathrm{C} 6-\mathrm{H} 6 \cdots \mathrm{O} 2$ and $\mathrm{C} 12-\mathrm{H} 12 \cdots \mathrm{O} 4$ interactions between pyridyl rings and carbonyl moieties stabilize the belt formation. Belts are connected to the supramolecular structure via $\mathrm{C} 4-\mathrm{H} 4 \cdots \mathrm{O} 5$ interactions between the pyridyl rings and oxido atoms and $\mathrm{C} 10-\mathrm{H} 10 \cdots \mathrm{O} 4$ interactions between the pyridyl rings and carbonyl moieties (Table S2, ESI $\dagger$ ). Channels along the $c$ axis are occupied by water molecules (Fig. 2). There are no significant $\pi \cdots \pi$ interactions present.

Vanadium atom in $\mathbf{4}$ is also six-coordinated having an octahedral geometry similar to 3 with a cis arrangement of the oxido oxygen atoms of $\mathrm{VO}_{2}{ }^{+}$group. The main difference in the structure of complex anion in comparison to the structure 3 is in the mutual orientation of the two bidentate 3-hydroxypicolinato ligands. While in compound 3 the coordinated picolinato nitrogen atoms are in a mutual cis position, in compound $\mathbf{4}$ they are in a mutual trans position and thus the carboxylate oxygen atoms are in mutual cis orientation. The $\mathrm{V}-\mathrm{N}$ bond in $\mathbf{4}$ is shorter than in $\mathbf{3}$ (2.116(4) $\AA$ vs. 2.332(5) and 2.322(4) ̊), while the $\mathrm{V}-\mathrm{O}$ bond in 4 is

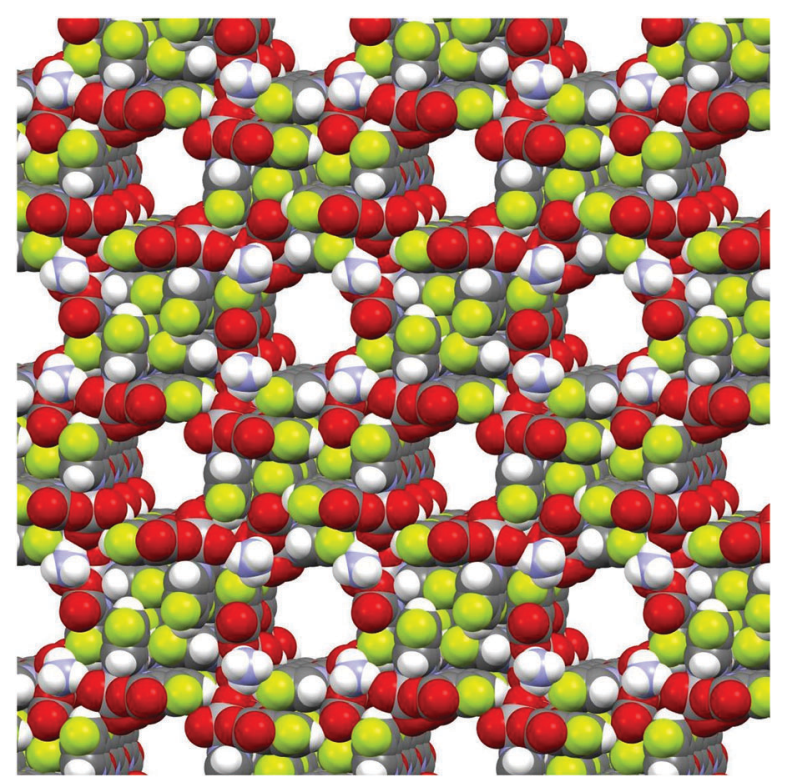

Fig. 2 Space filled representation of the packing in $3 \cdot 1 \cdot 6 \mathrm{H}_{2} \mathrm{O}$ showing the channels along the $c$-axis. Water molecules filling the channels have been omitted for clarity. 


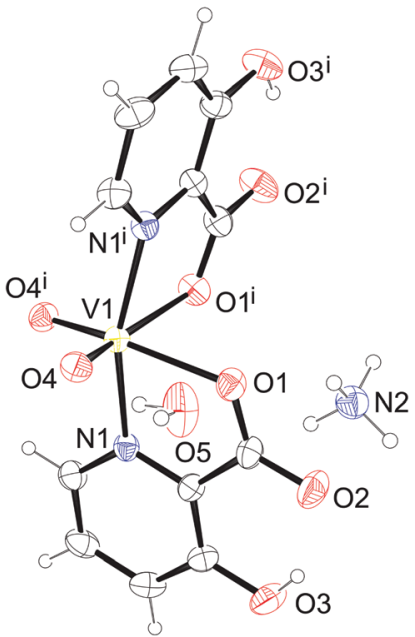

Fig. 3 Asymmetric unit of $\mathrm{NH}_{4}\left[\mathrm{VO}_{2}(\text { Hhypic })_{2}\right] \cdot \mathrm{H}_{2} \mathrm{O} \quad\left(4 \cdot \mathrm{H}_{2} \mathrm{O}\right)$. Thermal ellipsoids are shown with $30 \%$ probability level at $293 \mathrm{~K}$.

elongated compared to 3 (2.149(4) ̊ vs. 1.964(4) and 1.988(4) $\AA$ ). The octahedral geometry displays a distortion with angles $\mathrm{N} 1-\mathrm{V} 1-\mathrm{N} 1^{\mathrm{i}}$ of $162.3(2)^{\circ}$ and $\mathrm{O} 1-\mathrm{V} 1-\mathrm{O} 4^{\mathrm{i}}$ of $161.15(16)^{\circ}$.

Ammonium cations, complex anions and solvate water in the crystal structure of $\mathbf{4} \cdot \mathrm{H}_{2} \mathrm{O}$ form hydrogen-bonded infinite 2D layers along the $a b$ plane (Fig. S2, ESI $\dagger$ ). The ammonium cation is connected to three adjacent $\left[\mathrm{VO}_{2}(\text { Hhypic })_{2}\right]^{-}$complex anions through two bifurcated hydrogen-bonds N2-H2A $\cdots \mathrm{O} 1$ and $\mathrm{N} 2-\mathrm{H} 2 \mathrm{~A} \cdots \mathrm{O} 2$ with carboxylato units of two complex anions and through two N2-H2B ‥O4 hydrogen bonds with both oxido atoms of $\mathrm{VO}_{2}{ }^{+}$unit of the third complex anion (Table S3, $\mathrm{ESI}+$ ). The solvate water molecule is involved in O5-H5A $\cdots \mathrm{O} 4$ hydrogen-bonding with the oxido atoms of two adjacent $\mathrm{VO}_{2}{ }^{+}$ units. The $\mathrm{C} 6-\mathrm{H} 6 \cdots \mathrm{O} 2$ interaction between the pyridyl ring and carbonyl oxygen atom of the adjacent complex anion further stabilize the layer formation. Layers are connected into the supramolecular structure along the $c$ axis via $\mathrm{N} 2-\mathrm{H} 2 \mathrm{~B} \cdots \mathrm{O} 3$ interactions between the ammonium cation and the hydroxyl group as well as $\mathrm{C} 4-\mathrm{H} 4 \cdots \mathrm{O} 4$ interactions between the pyridyl ring and the oxido atoms of the $\mathrm{VO}_{2}{ }^{+}$unit and by $\pi-\pi$ interactions with a $\mathrm{Cg} 3 \cdots \mathrm{Cg} 3$ centroid-to-centroid distance of 3.736(3) Å (Fig. S3 and Table S4, ESI†).

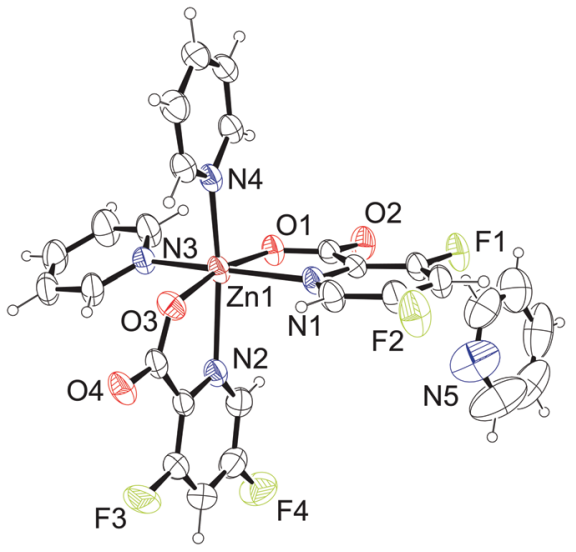

Fig. 5 Asymmetric unit of $\left[\mathrm{Zn}(\mathrm{picFF})_{2}(\mathrm{py})_{2}\right] \cdot \mathrm{py}(6 \cdot \mathrm{py})$. Thermal ellipsoids are shown with $30 \%$ probability level at $293 \mathrm{~K}$.

Crystal structures of $\left[\mathrm{Zn}(\mathrm{picFF})_{2}\left(\mathrm{H}_{2} \mathrm{O}\right)_{2}\right](5),\left[\mathrm{Zn}(\mathrm{picFF})_{2}(\mathrm{py})_{2}\right] \cdot \mathrm{py}$ (6. py), $\left[\mathrm{Zn}(\text { picFF })_{2}(\mathrm{DMAP})_{2}\right]^{2} / \mathrm{H}_{3} \mathrm{H}_{2} \mathrm{O}\left(7.2 / 3 \mathrm{H}_{2} \mathrm{O}\right)$ and $\left[\mathrm{Zn}(\mathrm{picFF})_{2}(\mathrm{phen})\right] \cdot$ ${ }_{2} \mathbf{C H C l}_{3}\left(\mathbf{8} \cdot 2 \mathrm{CHCl}_{3}\right)$. Crystals of compounds 5-8 were grown from the reaction mixtures after a few days of slow evaporation of the solvents. In air the crystals of $\mathbf{8} \cdot 2 \mathrm{CHCl}_{3}$ gradually lose solvate molecules and transform into solvate-free 8. Diagrams of the structures of complexes 5-8 are shown in Fig. 4-7, and selected bond distances and angles are summarized in Tables 3-6.

The complex 5 crystallizes in the triclinic space group $P \overline{1}$. The asymmetric unit contains one half of the complex with the zinc atom sitting on the inversion center. The zinc atom is octahedrally coordinated with two bidentate picFF ligands in the equatorial position in a trans arrangement and with two water molecules in the axial positions. The distance between the zinc and carboxyl oxygen (Zn1-O1 $=2.0541(12) \AA$ ) is shorter than the bond between zinc and water $(\mathrm{Zn} 1-\mathrm{O} 3=2.2092(14) \AA)$. The Zn1-N1 distance is 2.1020(14) $\AA$. The angles between the trans oriented atoms are $180^{\circ}$ due to the center of symmetry. The chelate angle of the picFF ligand O1-Zn1-N1 is $79.49(5)^{\circ}$, the angle between the water and carboxyl oxygen atom O1-Zn1-O3 is $91.16(5)^{\circ}$, and the angle between the water and picolinato nitrogen atom O3-Zn1-N1 is $89.93(5)^{\circ}$.

The crystal structure of 5 is stabilized by hydrogen bonding between a coordinated water molecule acting as a hydrogen bond donor and a carbonyl atom acting as a hydrogen bond

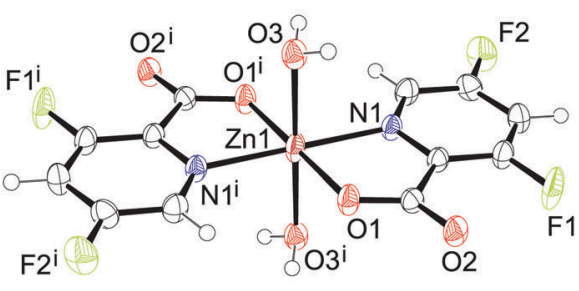

(a)

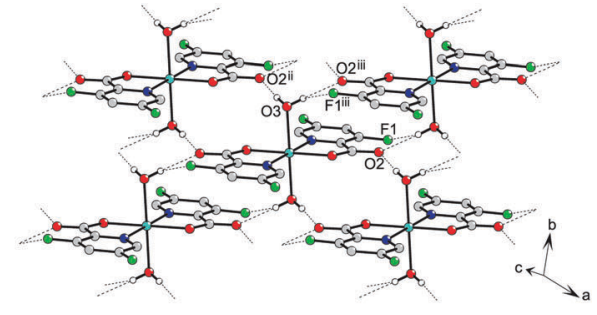

(b)

Fig. 4 (a) Structure of the compound $\left[\mathrm{Zn}(\text { picFF })_{2}\left(\mathrm{H}_{2} \mathrm{O}\right)_{2}\right]$ (5). Thermal ellipsoids are shown with $30 \%$ probability level at $293 \mathrm{~K}$. (b) The layer of hydrogen-bonded molecules in 6 . Dashed lines indicate $\mathrm{O}-\mathrm{H} \cdots \mathrm{O} / \mathrm{F}$ hydrogen bonds. Symmetry codes: (i) $-x+1,-y+1,-z+1$; (ii) $x-1, y, z$; (iii) $-x+1$, $-y+2,-z+1$. 


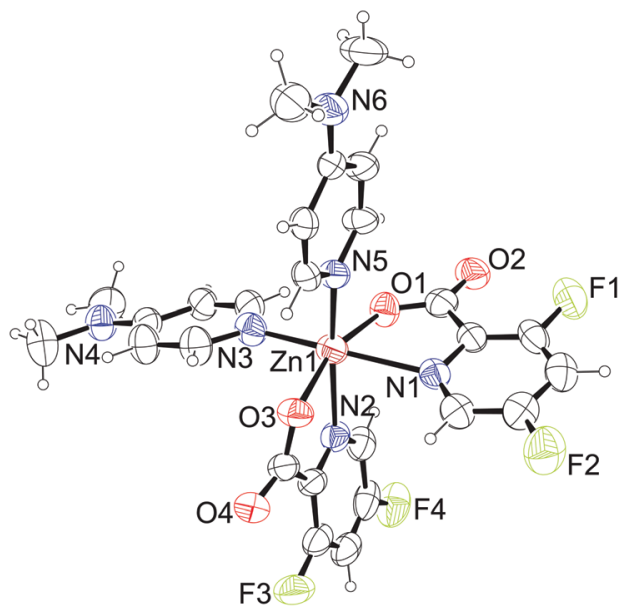

Fig. 6 Structure of $\left[\mathrm{Zn}(\text { picFF })_{2}(\mathrm{DMAP})_{2}\right]$ (7). For clarity only one out of three crystallographically independent molecules is shown. Thermal ellipsoids are shown with $30 \%$ probability level at $293 \mathrm{~K}$.

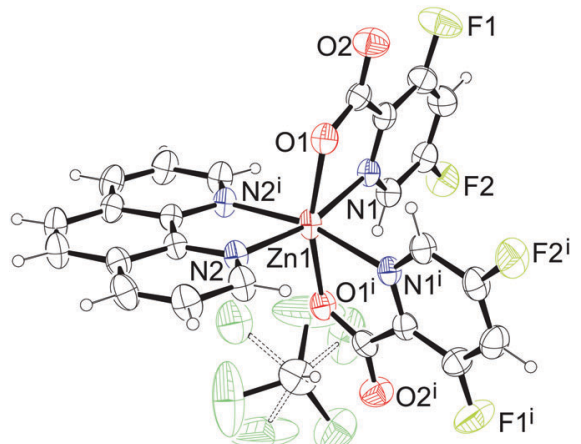

Fig. 7 Structure of $\left[\mathrm{Zn}(\text { picFF })_{2}(\right.$ phen) $) \cdot 2 \mathrm{CHCl}_{3} \quad\left(8 \cdot 2 \mathrm{CHCl}_{3}\right)$. Thermal ellipsoids are shown with $30 \%$ probability level at $293 \mathrm{~K}$. Symmetry code: (i) $-x+2, y,-z+1 / 2$

acceptor forming centrosymmetric hydrogen bonding with a $\mathrm{R}_{4}^{2}(8)$ ring motif. The water molecule is also involved in hydrogen bonding with the fluorine atom of the adjacent molecule forming a $\mathrm{R}_{1}^{2}(6)$ ring motif. These interactions form hydrogenbonded layers parallel to the $a b$ plane (Fig. 4(b) and Table S5, ESI $\dagger$ ). The layers are connected into the supramolecular structure along the $c$ axis via $\mathrm{C}-\mathrm{H} \cdots \mathrm{F}$ interactions and $\pi-\pi$ interactions with a $\mathrm{Cg} 3 \cdots \mathrm{Cg} 3$ centroid-to-centroid distance of 3.6302(10) ̊ (Tables S5 and S6, ESI $†$ ).

Table 3 Selected bond distances $(\AA \AA)$ and angles $\left({ }^{\circ}\right)$ for $\left[\mathrm{Zn}(\text { picFF })_{2}\left(\mathrm{H}_{2} \mathrm{O}\right)_{2}\right](\mathbf{5})$

\begin{tabular}{llll}
\hline Distance $(\AA)$ & & & \\
\hline Zn1-O1 & $2.0541(12)$ & Zn1-N1 & $2.1020(14)$ \\
Zn1-O3 & $2.2092(14)$ & & \\
\hline Angle $\left(^{\circ}\right)$ & & & \\
\hline O1-Zn1-O3 & $91.16(5)$ & O1-Zn1-N1 ${ }^{i}$ & $100.51(5)$ \\
O1-Zn1-O3 & & & \\
O1-Zn1-N1 & $88.84(5)$ & O3-Zn1-N1 & $89.93(5)$ \\
& $79.49(5)$ & O3-Zn1-N1 & $90.07(5)$
\end{tabular}

Symmetry code: (i) $-x+1,-y+1,-z+1$.
Table 4 Selected bond distances $(\AA)$ and angles $\left({ }^{\circ}\right)$ for $\left[\mathrm{Zn}(\mathrm{picFF})_{2}(\mathrm{py})_{2}\right] \cdot$ py (6.py)

\begin{tabular}{llll}
\hline Distance $(\AA)$ & & & \\
\hline Zn1-O1 & $2.0438(16)$ & Zn1-N2 & $2.308(2)$ \\
Zn1-O3 & $2.0335(17)$ & Zn1-N3 & $2.164(2)$ \\
Zn1-N1 & $2.2267(19)$ & Zn1-N4 & $2.156(2)$ \\
\hline Angle $\left(^{\circ}\right)$ & & & \\
\hline O1-Zn1-O3 & $168.56(7)$ & O3-Zn1-N4 & $89.33(8)$ \\
O1-Zn1-N1 & $76.30(7)$ & N1-Zn1-N2 & $88.76(7)$ \\
O1-Zn1-N2 & $96.26(7)$ & N1-Zn1-N3 & $163.54(8)$ \\
O1-Zn1-N3 & $87.88(7)$ & N1-Zn1-N4 & $90.91(8)$ \\
O1-Zn1-N4 & $99.60(7)$ & N2-Zn1-N3 & $88.48(7)$ \\
O3-Zn1-N1 & $96.57(7)$ & N2-Zn1-N4 & $163.59(7)$ \\
O3-Zn1-N2 & $74.42(7)$ & N3-Zn1-N4 & $96.26(8)$ \\
O3-Zn1-N3 & $98.31(8)$ & &
\end{tabular}

Table 6 Selected bond distances $(\AA)$ and angles $\left(^{\circ}\right)$ for $\left[\mathrm{Zn}(\text { picFF })_{2}(\right.$ phen $\left.)\right]$. $2 \mathrm{CHCl}_{3}\left(8 \cdot 2 \mathrm{CHCl}_{3}\right)$

\begin{tabular}{|c|c|c|c|}
\hline \multicolumn{4}{|l|}{ Distance $(\AA)$} \\
\hline Zn1-O1 & $2.046(2)$ & Zn1-N2 & $2.164(2)$ \\
\hline Zn1-N1 & $2.194(2)$ & & \\
\hline \multicolumn{4}{|l|}{ Angle $\left(^{\circ}\right)$} \\
\hline$\overline{\mathrm{O} 1-\mathrm{Zn} 1-\mathrm{O} 1^{\mathrm{i}}}$ & 163.53(12) & $\mathrm{N} 1-\mathrm{Zn} 1-\mathrm{N} 1^{\mathrm{i}}$ & $96.19(13)$ \\
\hline O1-Zn1-N1 & $77.12(9)$ & N1-Zn1-N2 & $165.96(10)$ \\
\hline O1-Zn1-N2 & $93.14(9)$ & $\mathrm{N} 1-\mathrm{Zn} 1-\mathrm{N} 2^{\mathrm{i}}$ & $94.19(9)$ \\
\hline $\mathrm{O} 1-\mathrm{Zn} 1-\mathrm{N} 1^{\mathrm{i}}$ & $91.82(9)$ & $\mathrm{N} 2-\mathrm{Zn} 1-\mathrm{N} 2^{\mathrm{i}}$ & $77.32(13)$ \\
\hline $\mathrm{O} 1-\mathrm{Zn} 1-\mathrm{N} 2^{\mathrm{i}}$ & $99.72(10)$ & & \\
\hline
\end{tabular}

The compound 6.py crystallizes as a pyridine solvate in the monoclinic space group $P 2_{1} / c$ with the formula $\left[\mathrm{Zn}(\mathrm{picFF})_{2^{-}}\right.$ (py $\left.)_{2}\right]$.py. The asymmetric unit contains one molecule of the complex and one molecule of pyridine. The complex has a distorted octahedral geometry, with a cis-octahedral arrangement of py ligands on the zinc central atom. Two py molecules are bound to the zinc through the pyridine nitrogen atoms with $\mathrm{Zn}-\mathrm{N}$ distances of 2.164(2) and 2.156(2) $\AA$ in cis positions with the N3-Zn1-N4 angle of $96.26(8)^{\circ}$, while the two bidentate picFF ligands are coordinated with the picolinato nitrogen atoms in a mutual cis position [N1-Zn1-N2 $\left.=88.76(7)^{\circ}\right]$ with the $\mathrm{Zn}-\mathrm{N}$ distances of 2.2267(19) and 2.308(2) $\AA$, being longer than those in compound 5. Carboxyl oxygen atoms are bound to the zinc atom in mutual trans positions $\left[\mathrm{O} 1-\mathrm{Zn} 1-\mathrm{O} 3=168.56(7)^{\circ}\right]$ with $\mathrm{Zn}-\mathrm{O}$ distances 2.0438(16) and 2.0335(17) A.

The supramolecular structure of $\mathbf{6}$.py is stabilized by various $\mathrm{C}-\mathrm{H} \cdots \mathrm{O}$ and $\mathrm{C} 14-\mathrm{H} 14 \cdots \mathrm{F} 2$ hydrogen bonding interactions forming layers along the $b c$ axis (Fig. S4 and Table S7, ESI $\dagger$ ). Pyridine solvate molecules are part of these layers and are connected through C15-H15 $\cdots \mathrm{N} 5$ hydrogen bonding and $\pi \cdots \pi$ interactions with a $\mathrm{Cg} 4 \cdots \mathrm{Cg} 7$ centroid-to-centroid distance of $4.170(3) \AA$ A. The layers are connected into the supramolecular structure through $\pi \cdots \pi$ interactions with a $\mathrm{Cg} 3 \cdots \mathrm{Cg} 5$ centroidto-centroid distance of 4.0362(17) $\AA$ between the picolinate and pyridine moieties that are part of adjacent complexes (Table S8, ESI $\dagger$ ). 
Table 5 Selected bond distances ( $(\AA)$ and angles ( $\left.{ }^{\circ}\right)$ for $\left[\mathrm{Zn}(\text { picFF })_{2}(\mathrm{DMAP})_{2}\right] \cdot 2 / 3 \mathrm{H}_{2} \mathrm{O}\left(\mathbf{7} \cdot 2 / 3 \mathrm{H}_{2} \mathrm{O}\right)$

\begin{tabular}{|c|c|c|c|c|c|}
\hline \multicolumn{6}{|l|}{ Distance $(\AA)$} \\
\hline Zn1-O3 & $2.082(3)$ & $\mathrm{Zn} 2-\mathrm{O} 7$ & $2.068(3)$ & $\mathrm{Zn3-O11}$ & $2.066(3)$ \\
\hline Zn1-N1 & $2.344(4)$ & Zn2-N7 & $2.267(4)$ & Zn3-N13 & $2.195(4)$ \\
\hline Zn1-N3 & $2.075(4)$ & Zn2-N9 & $2.133(3)$ & Zn3-N15 & $2.091(3)$ \\
\hline Zn1-N5 & $2.078(3)$ & Zn2-N11 & $2.101(3)$ & Zn3-N17 & $2.120(4)$ \\
\hline \multicolumn{6}{|l|}{ Angle $\left(^{\circ}\right)$} \\
\hline O1-Zn1-N1 & $74.48(14)$ & O5-Zn2-N7 & $75.25(13)$ & O9-Zn3-N13 & $75.55(15)$ \\
\hline O1-Zn1-N2 & $91.51(15)$ & $\mathrm{O} 5-\mathrm{Zn} 2-\mathrm{N} 8$ & $89.91(12)$ & O9-Zn3-N14 & $90.25(15)$ \\
\hline O1-Zn1-N3 & $95.37(15)$ & O5-Zn2-N9 & $93.47(12)$ & O9-Zn3-N15 & $93.19(13)$ \\
\hline O1-Zn1-N5 & $96.06(13)$ & O5-Zn2-N11 & $100.92(12)$ & O9-Zn3-N17 & $101.33(13)$ \\
\hline O3-Zn1-N1 & $92.24(14)$ & $\mathrm{O} 7-\mathrm{Zn} 2-\mathrm{N} 7$ & $96.74(12)$ & O11-Zn3-N13 & $94.63(16)$ \\
\hline $\mathrm{O} 3-\mathrm{Zn} 1-\mathrm{N} 2$ & $75.98(14)$ & $\mathrm{O} 7-\mathrm{Zn} 2-\mathrm{N} 8$ & 75.91(12) & O11-Zn3-N14 & $75.46(15)$ \\
\hline O3-Zn1-N3 & $96.31(14)$ & $\mathrm{O} 7-\mathrm{Zn} 2-\mathrm{N} 9$ & $94.56(12)$ & O11-Zn3-N15 & $95.67(13)$ \\
\hline N2-Zn1-N3 & $89.94(14)$ & N8-Zn2-N9 & $90.56(12)$ & N14-Zn3-N15 & $90.46(13)$ \\
\hline N2-Zn1-N5 & 168.14(15) & N8-Zn2-N11 & $168.56(13)$ & N14-Zn3-N17 & $166.93(16)$ \\
\hline N3-Zn1-N5 & $98.39(15)$ & N9-Zn2-N11 & $92.43(14)$ & N15-Zn3-N17 & $94.87(13)$ \\
\hline
\end{tabular}

The compound $7 \cdot 2 / 3 \mathrm{H}_{2} \mathrm{O}$ crystallizes as a hydrate in the orthorhombic space group $\mathrm{Pbca}$ with the formula $\left[\mathrm{Zn}(\text { picFF })_{2}(\mathrm{DMAP})_{2}\right]^{2}{ }^{2} / 3 \mathrm{H}_{2} \mathrm{O}$. The asymmetric unit contains three crystallographically independent complex molecules and two water solvate molecules. All three independent complexes have a distorted octahedral geometry, with a cis-octahedral arrangement of DMAP ligands on the zinc central atom analogous to 6.py. The geometric parameters for all three complexes are very similar (Table 5). DMAP molecules are bound to the zinc through the pyridine nitrogen atoms in cis positions with $\mathrm{Zn}-\mathrm{N}$ distances in the range of 2.075(4)-2.133(3) $\AA$ and $\mathrm{N}_{\text {DMAP }}-\mathrm{Zn}-$ $\mathrm{N}_{\text {DMAP }}$ angles in the range of 92.43(14)-98.39(15) ${ }^{\circ}$. Two bidentate picFF ligands are coordinated with the picolinato nitrogen atoms in a mutual cis position $\left[\mathrm{N}_{\text {pic }}-\mathrm{Zn}-\mathrm{N}_{\text {pic }}\right.$ in the range of 83.67(12)90.93(12) $)^{\circ}$ with $\mathrm{Zn}-\mathrm{N}_{\text {pic }}$ distances in the range 2.195(4)-2.344(4) $\mathrm{A}$, being longer than those in compound 5. Carboxyl oxygen atoms are bound to the zinc atom in mutual trans positions [O-Zn-O in the range of $\left.162.84(12)-163.74(11)^{\circ}\right]$ with $\mathrm{Zn}-\mathrm{O}$ distances in the range of 2.056(3)-2.089(3) $\AA$.

The supramolecular structure of $7 \cdot 2 / 3 \mathrm{H}_{2} \mathrm{O}$ is stabilized by several $\mathrm{C}-\mathrm{H} \cdots \mathrm{O}$ and $\mathrm{C} 26-\mathrm{H} 26 \mathrm{~A} \cdots \mathrm{F} 3$ hydrogen bonding interactions in all three dimensions (Table S7, ESI $\dagger$ ). DMAP ligands are also involved in $\mathrm{C}-\mathrm{H} \cdots \pi$ and $\pi \cdots \pi$ interactions $[\mathrm{Cg} 6 \cdots \mathrm{Cg} 17$ centroid-to-centroid distance of 3.917(2) $\AA$ ] connecting three adjacent molecules (Fig. S5 and Table S8, ESI $\dagger$ ).

The compound $\mathbf{8} \cdot 2 \mathrm{CHCl}_{3}$ crystallizes in the monoclinic space group $C 2 / c$ as a chloroform solvate $(1: 2)$ with the formula $\left[\mathrm{Zn}(\mathrm{picFF})_{2}\right.$ (phen)] $2 \mathrm{CHCl}_{3}$ and the asymmetric unit contains one half of the complex molecule and one solvate molecule since the zinc metal center is positioned on the two-fold rotation axis. The zinc central atom is hexacoordinated with the same octahedral arrangement as in 6 and 7. Phen is coordinated to the zinc with a Zn-N distance of 2.164(2) $\AA$ and the picFF ligands with a somewhat longer $\mathrm{Zn}-\mathrm{N}$ distance of 2.194(2) A and a Zn-O distance of 2.046(2) $\AA$. The two picolinic nitrogen atoms are cis to each other $\left[\mathrm{N} 1-\mathrm{Zn} 1-\mathrm{N} 1^{\mathrm{i}}=96.19(13)^{\circ}\right]$, and the two carboxyl oxygen atoms are in a trans arrangement $\left[\mathrm{O} 1-\mathrm{Zn} 1-\mathrm{O} 1^{\mathrm{i}}=163.53(12)^{\circ}\right]$.

In the crystal structure of $\mathbf{8} \cdot 2 \mathrm{CHCl}_{3}$ the complex molecules are connected into the infinite belt along the $c$ axis through $\mathrm{C} 4-\mathrm{H} 4 \cdots \mathrm{O} 2$ interactions and chloroform solvate molecules are connected to the complex molecules through bifurcated $\mathrm{C} 13-\mathrm{H} 13 \cdots \mathrm{O} 1 / \mathrm{O} 2$ interactions with the carboxylato groups. The $\pi \cdots \pi$ stacking interactions between adjacent phen moieties with a Cg6 ‥Cg17 centroid-to-centroid distance of 3.706(3) Å connect the belts into a three-dimensional structure (Fig. S6, Tables S7 and S8, ESI $\dagger$ ).

Crystal structures of $\left[\mathrm{Zn}(\mathrm{Hhypic})_{2}(\mathrm{MeOH})_{2}\right](10),\left[\mathrm{Zn}(\text { Hhypic })_{2^{-}}\right.$ (DMAP)( $\left.\left.\mathrm{H}_{2} \mathrm{O}\right)\right]$ (11) and [Zn(Hhypic) $)_{2}($ phen)] (12). A small amount of the crystals of $\mathbf{1 0}$ was obtained during the unsuccessful synthesis of $\mathbf{1 1}$ when using methanol as the solvent. The complex 10 crystallizes in the monoclinic space group $C 2 / c$. The asymmetric unit contains one half of the complex with the zinc atom sitting on the inversion center. The zinc atom is octahedrally coordinated with two bidentate Hhypic ligands in the equatorial position in trans arrangement and with two methanol molecules in the axial positions (Fig. 8). The distance between zinc and the carboxyl oxygen $(\mathrm{Zn} 1-\mathrm{O} 1=2.0750(10) \AA)$ is shorter than the bond between zinc and the methanol oxygen atom $(\mathrm{Zn} 1-\mathrm{O} 4=$ 2.1930(11) Å). The Zn1-N1 distance is 2.0765(14) A. The chelate angle of the Hhypic ligand O1-Zn1-N1 is $80.73(4)^{\circ}$, the angle between the methanol and carboxyl oxygen atoms O1-Zn1-O4 is 93.85(4) ${ }^{\circ}$, and the angle between the methanol oxygen atom and the picolinato nitrogen atom $\mathrm{O} 4-\mathrm{Zn} 1-\mathrm{N} 1$ is $90.03(5)^{\circ}$ (Table 7).

The crystal structure of $\mathbf{1 0}$ is stabilized by hydrogen bonding between a coordinated methanol molecule acting as a hydrogen bond donor and a carbonyl atom of an adjacent complex acting 


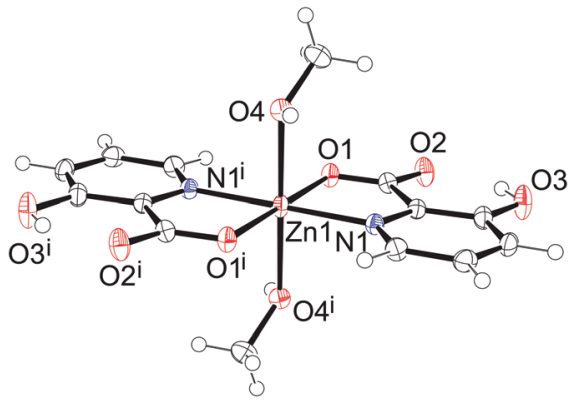

Fig. 8 Structure of $\left[\mathrm{Zn}(\mathrm{Hhypic})_{2}(\mathrm{MeOH})_{2}\right]$ (10). Thermal ellipsoids are shown with a $50 \%$ probability level at $150 \mathrm{~K}$. Symmetry code: (i) $-x+1 / 2$, $-y+1 \frac{1}{2},-z$.

Table 7 Selected bond distances $(\AA \AA)$ and angles $\left({ }^{\circ}\right)$ for $\left[\mathrm{Zn}(\text { Hhypic })_{2^{-}}\right.$ $\left.(\mathrm{MeOH})_{2}\right](10)$

\begin{tabular}{llll}
\hline Distance $(\AA)$ & & & \\
\hline Zn1-O1 & $2.0750(10)$ & Zn1-N1 & $2.0765(14)$ \\
Zn1-O4 & $2.1930(11)$ & & \\
\hline Angle $\left(^{\circ}\right)$ & & & \\
\hline O1-Zn1-O4 & $93.85(4)$ & O1-Zn1-N1 ${ }^{\mathrm{i}}$ & $99.27(4)$ \\
O1-Zn1-O4 & $86.15(4)$ & O4-Zn1-N1 & $90.03(5)$ \\
O1-Zn1-N1 & $80.73(4)$ & O4-Zn1-N1 & $89.97(5)$
\end{tabular}

Symmetry code: (i) $-x+1 / 2,-y+1 \frac{1}{2},-z$.

as a hydrogen bond acceptor forming centrosymmetric hydrogen bonding with a $\mathrm{R}_{2}^{2}(12)$ ring motif and a chain along the $b$ axis is formed. These chains are further connected into an infinite layer along the bc plane through the formation of $\mathrm{C}-\mathrm{H} \cdots \mathrm{O}$ hydrogen bonding, with the picolinic moiety as a hydrogen bond donor and the methanol molecule as a hydrogen bond acceptor (Fig. S7 and Table S9, ESI $\dagger$ ). There are no significant $\pi \cdots \pi$ interactions present.

The compound $\mathbf{1 1}$ crystallizes in the orthorhombic space group Pnna with the formula $\left[\mathrm{Zn}(\text { Hhypic })_{2}(\mathrm{DMAP})\left(\mathrm{H}_{2} \mathrm{O}\right)\right]$. The asymmetric unit contains one half of the complex with a zinc atom, DMAP and water sitting on the two-fold axis. The zinc atom is octahedrally coordinated with two bidentate Hhypic ligands in the equatorial position in trans arrangement and with one DMAP and one water molecule in the axial positions (Fig. 9). The distance between the zinc and carboxyl oxygen $(\mathrm{Zn} 1-\mathrm{O} 1=2.1028(11) \AA)$ is shorter than the bond between zinc and the water oxygen atom $(\mathrm{Zn} 1-\mathrm{O} 4=2.1578(19) \AA)$. The Zn1-N1 distance is 2.1350(14) $\AA$ and the DMAP is coordinated to the zinc with a Zn1-N2 distance of 2.161(2) A. The chelate angle of the Hhypic ligand O1-Zn1-N1 is 79.18(5) ${ }^{\circ}$, the angle between the water and carboxyl oxygen atoms O1-Zn1-O4 is $88.62(3)^{\circ}$, and the angle between the water oxygen atom and picolinato nitrogen atom O4-Zn1-N1 is 86.21(3) ${ }^{\circ}$ (Table 8).

The supramolecular structure of $\mathbf{1 1}$ is stabilized by hydrogen bonding between a coordinated water molecule acting as a hydrogen bond donor and carboxylic oxygen atoms of two adjacent complexes acting as hydrogen bond acceptors as well as by the $\mathrm{C}-\mathrm{H} \cdots \mathrm{O}$ interactions between the Hhypic moiety and

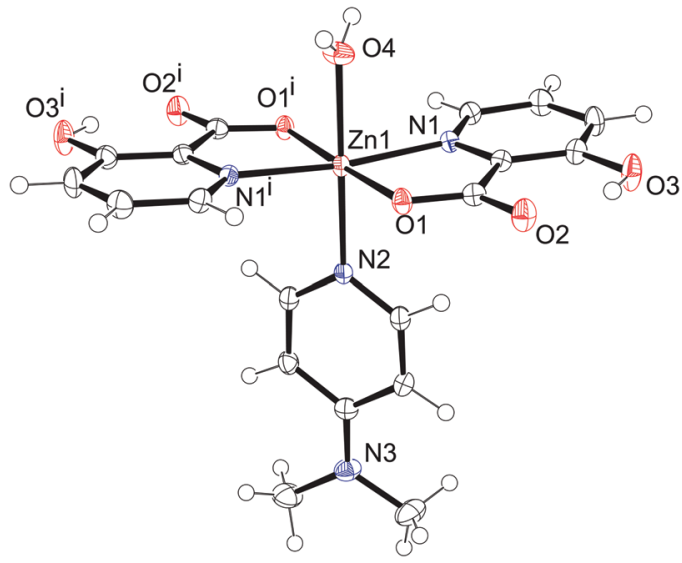

Fig. 9 Structure of $\left[\mathrm{Zn}(\text { Hhypic })_{2}(\mathrm{DMAP})\left(\mathrm{H}_{2} \mathrm{O}\right)\right]$ (11). Thermal ellipsoids are shown with a $50 \%$ probability level at $150 \mathrm{~K}$. Symmetry code: (i) $-x+1 \frac{1}{2}$, $-y+1, z$

Table 8 Selected bond distances $(\hat{A})$ and angles $\left(^{\circ}\right)$ for $\left[\mathrm{Zn}(\text { Hhypic })_{2^{-}}\right.$ (DMAP) $\left.\left(\mathrm{H}_{2} \mathrm{O}\right)\right](\mathbf{1 1})$

\begin{tabular}{llll}
\hline Distance $(\AA)$ & & & \\
\hline $\mathrm{Zn} 1-\mathrm{O} 1$ & $2.1028(11)$ & $\mathrm{Zn} 1-\mathrm{N} 1$ & $2.1350(14)$ \\
$\mathrm{Zn} 1-\mathrm{O} 4$ & $2.1578(19)$ & $\mathrm{Zn} 1-\mathrm{N} 2$ & $2.161(2)$ \\
\hline Angle $\left(^{\circ}\right)$ & & & \\
\hline $\mathrm{O} 1-\mathrm{Zn} 1-\mathrm{O} 1^{\mathrm{i}}$ & $177.24(6)$ & $\mathrm{O} 1-\mathrm{Zn} 1-\mathrm{N} 2$ & $91.38(3)$ \\
$\mathrm{O} 1-\mathrm{Zn} 1-\mathrm{O} 4$ & $88.62(3)$ & $\mathrm{N} 1-\mathrm{Zn} 1-\mathrm{O} 4$ & $86.21(3)$ \\
$\mathrm{O}^{\circ}-\mathrm{Zn} 1-\mathrm{N} 1$ & $79.18(5)$ & $\mathrm{N} 1-\mathrm{Zn} 1-\mathrm{N} 1^{\mathrm{i}}$ & $172.41(7)$ \\
$\mathrm{O}^{\mathrm{i}}-\mathrm{Zn} 1-\mathrm{N} 1^{\mathrm{i}}$ & $100.64(5)$ & $\mathrm{N} 1-\mathrm{Zn} 1-\mathrm{N} 2$ & $93.79(3)$
\end{tabular}

Symmetry code: (i) $-x+1 \frac{1}{2},-y+1, z$.

the carbonyl atom of the adjacent complex forming a chain along the $a$ axis (Fig. 10 and Table S9, ESI $\dagger$ ). The chains are further connected into the 3D structure through $\mathrm{C}-\mathrm{H} \cdots \mathrm{O}$ and $\mathrm{C}-\mathrm{H} \cdots \pi$ interactions (Fig. S8 and Table S9, ESI $\dagger$ ).

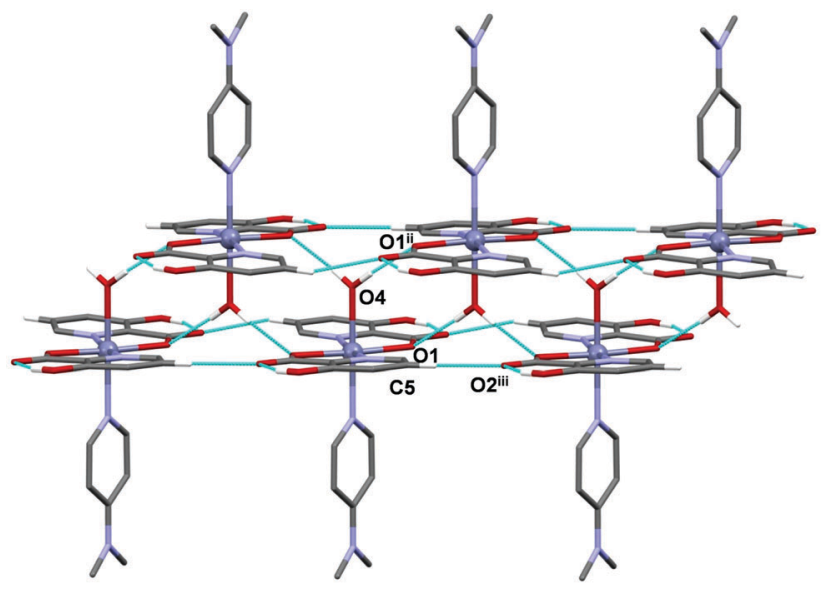

Fig. 10 A chain of hydrogen-bonded molecules in 11. Blue dashed lines indicate $\mathrm{O}-\mathrm{H} \ldots \mathrm{O}$ and $\mathrm{C}-\mathrm{H} \ldots \mathrm{O}$ interactions. $\mathrm{H}$ atoms not involved in the motif shown have been omitted for clarity. Symmetry codes: (ii) $x+1 / 2, y$, $-z$; (iii) $x+1, y, z$. 


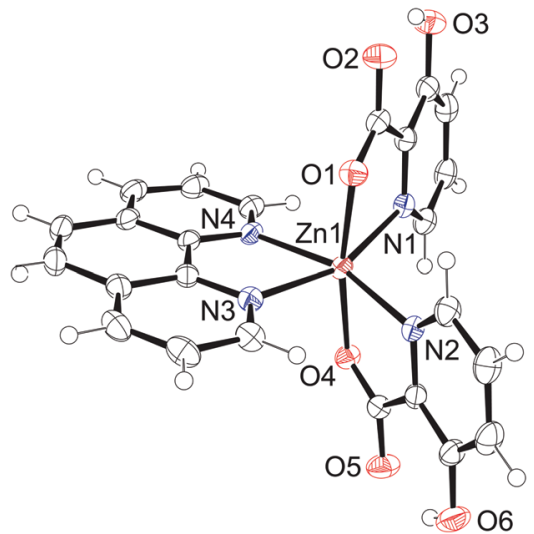

Fig. 11 Asymmetric unit of [Zn(Hhypic) 2 (phen)] (12). Thermal ellipsoids are shown with $50 \%$ probability level at $150 \mathrm{~K}$.

Table 9 Selected bond distances (Å) and angles ( $\left.{ }^{\circ}\right)$ for [Zn(Hhypic) ${ }_{2}($ phen) $)$ (12)

\begin{tabular}{llll}
\hline Distance (̊) & & & \\
\hline Zn1-O1 & $2.1059(11)$ & Zn1-N2 & $2.1000(13)$ \\
Zn1-O4 & $2.0907(11)$ & Zn1-N3 & $2.2339(13)$ \\
Zn1-N1 & $2.1455(13)$ & Zn1-N4 & $2.1573(13)$ \\
\hline Angle $\left({ }^{\circ}\right)$ & & & \\
\hline O1-Zn1-O4 & $170.64(5)$ & O4-Zn1-N4 & $92.45(5)$ \\
O1-Zn1-N1 & $78.16(5)$ & N1-Zn1-N2 & $106.11(5)$ \\
O1-Zn1-N2 & $94.27(5)$ & N1-Zn1-N3 & $159.55(5)$ \\
O1-Zn1-N3 & $87.84(5)$ & N1-Zn1-N4 & $90.30(5)$ \\
O1-Zn1-N4 & $95.55(5)$ & N2-Zn1-N3 & $89.58(5)$ \\
O4-Zn1-N1 & $96.99(5)$ & N2-Zn1-N4 & $162.31(5)$ \\
O4-Zn1-N2 & $79.29(5)$ & N3-Zn1-N4 & $76.15(5)$ \\
O4-Zn1-N3 & $98.81(5)$ & &
\end{tabular}

The compound 12 crystallizes in the monoclinic space group $P 2_{1} / c$ with the formula $\left[\mathrm{Zn}(\text { Hhypic })_{2}(\mathrm{phen})\right]$ and the asymmetric unit contains one complex molecule (Fig. 11). The zinc atom is hexacoordinated with the same octahedral arrangement as in $\mathbf{8}$. Phen is coordinated to the zinc with $\mathrm{Zn}-\mathrm{N}$ distances of 2.1573(13) and 2.2339(13) $\AA$ and the Hhypic ligands with somewhat shorter $\mathrm{Zn}-\mathrm{N}$ distances of 2.1000(13) and 2.1455(13) $\AA$ and $\mathrm{Zn}-\mathrm{O}$ distances of 2.0907(11) and 2.1059(11) $\AA$. The two picolinic nitrogen atoms are cis to each other $\left[\mathrm{N} 1-\mathrm{Zn} 1-\mathrm{N} 2=106.11(5)^{\circ}\right]$, and the two carboxyl oxygen atoms are in a trans arrangement [O1-Zn1-O4 = 170.64(5) $)^{\circ}$ (Table 9).

The supramolecular structure of $\mathbf{1 2}$ is stabilized by several $\mathrm{C}-\mathrm{H} \cdots \mathrm{O}$ and $\pi \cdots \pi$ interactions in all three dimensions. The adjacent picolinato moieties are involved in $\pi \cdots \pi$ interactions with a Cg4 ‥Cg55 centroid-to-centroid distance of 3.8969(9) $\AA$ and the adjacent phen moieties are involved in $\pi \cdots \pi$ stacking interactions with centroid-to-centroid distances in the range 3.5779(9) to 3.6668(9) Å (Fig. S9, Tables S9 and S10, ESI $\dagger$ ).

\section{Structural comparison}

Valuable structural information is usually obtained by a solidstate X-ray diffraction study, however, when the compounds are introduced into a biological system certain chemical and biological changes can occur. EPR spectroscopy was found to be a powerful tool for the study of the solution structure and (bio)transformations of vanadium(Iv) species. ${ }^{25}$ Lately, we have been studying $\mathrm{V}^{\mathrm{IV}} \mathrm{O}$ compounds with picolinic acid and pyrazine derivatives concerning their structures and interactions with serum proteins. ${ }^{18}$ For compounds 1 and 2 three isomers were observed by EPR in an organic solvent or in aqueous solution. The $\mathrm{H}_{2}$ hypic was found to be the strongest ligand and the HpicFF the weakest one and thus different biotransformations at physiological $\mathrm{pH}$ in the presence of apo-transferrin and human serum albumin were observed. ${ }^{18}$ For the study of pharmacological activity all such generated species have to be taken into account and it is a challenge to obtain the observed solution-state species also in the solid state. In this respect, we were able to establish the first crystallographic evidence for the formation of an isomer of a vanadyl bis(picolinato) complex with the two pyridine nitrogen atoms in a mutual trans position previously observed only in the solution-state; the known solid-state structures possess a common arrangement with the two equatorial pyridine nitrogen atoms in a mutual cis position. ${ }^{18}$ We have extended our research on the diverse structural characteristics and supramolecular topologies of potential antidiabetic vanadium species ${ }^{23,26}$ also on vanadium(v) and zinc(II) compounds in order to study the flexibility of the coordination sphere and possible spatial arrangements in these species as well.

In general, for mononuclear bisoxidovanadate(v) compounds with two bidentate N,O ligands, such as picolinates, pyrazine-2carboxylates or their analogues, only three isomers are possible (Scheme 1). A search in the Cambridge Structural Database (CSD) gave five crystal structures. Structure (I) (Scheme 1) was observed in a $\mathrm{V}^{\mathrm{V}} \mathrm{O}_{2}$ compound with the 5-(methoxycarbonyl)picolinato ligand reported by Gätjens et al.,$^{27}$ in two compounds with the pyrazine-2-carboxylato ligand $\left(\mathrm{NBu}_{4}\right)\left[\mathrm{VO}_{2}(\mathrm{prz})_{2}\right]^{28}$ and $\mathrm{NH}_{4}\left[\mathrm{VO}_{2}(\mathrm{prz})_{2}\right]^{23}$ and in two compounds with 5-cyanopicolinato and 3-aminopyrazine-2-carboxylato ligands ${ }^{23}$ possessing nitrogen atoms coordinated to the $\mathrm{V}(\mathrm{v})$ metal center trans to the oxido oxygen atoms as observed also in 3 . The only report on structure (II) is the prototypical complex $\mathrm{NH}_{4}\left[\mathrm{VO}_{2}(\mathrm{pic})_{2}\right] \cdot \mathrm{H}_{2} \mathrm{O}$ prepared by Melchior $e t$ al. $^{29}$ with one picolinato nitrogen atom coordinated to the $\mathrm{V}$ metal center trans to the oxido oxygen and the other picolinato nitrogen atom coordinated in a trans position to the carboxyl oxygen atom. There were no reports on isomer (III) in the CSD and the 3-hydroxypicolinato complex 4 is thus the first crystallographic evidence for the formation of an isomer of a $\mathrm{V}^{\mathrm{V}} \mathrm{O}_{2}$ bis(picolinato) complex with the two pyridine nitrogen atoms in a mutual trans position. It has to be pointed out that 3-hydroxypicolinic acid possesses diverse ligation modes and can act

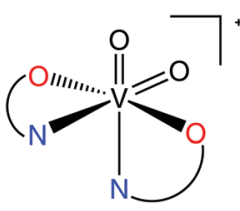

(I)

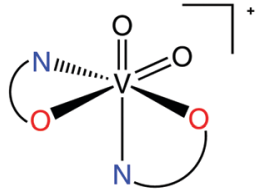

(II)
(III)

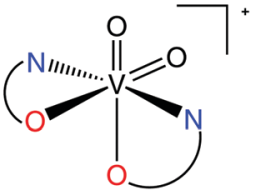

Scheme 1 Possible bis-chelated structures for $\mathrm{VO}_{2}{ }^{+}$species formed by a bidentate $\mathrm{N}, \mathrm{O}$-ligand. 
<smiles>[M]OC(=O)c1ncccc1O</smiles>

M(Hypic-O)

(i)<smiles></smiles>

(iii)

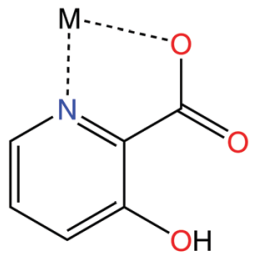

M(Hhypic- $N, O)$

(ii)

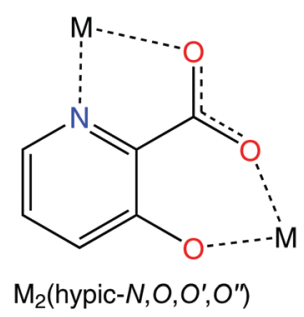

(iv)
Scheme 2 Possible binding modes of $\mathrm{H}_{2}$ hypic. (i) Monodentate Hhypic$\mathrm{O}$, (ii) bidentate Hhypic-N,O, (iii) bidentate Hhypic-O, $\mathrm{O}^{\prime}$ and (iv) bridging hypic-N,O, $\mathrm{O}^{\prime}, \mathrm{O}^{\prime \prime}$ ligation modes.

not just as $\mathrm{N}, \mathrm{O}-$ bidentate $\mathrm{Hhypic}^{-}$ligand but also as a monodentate O-ligand as observed in $\mathrm{Na}\left[\mathrm{VO}(\text { Hhypic-N,O })_{2}(\right.$ Hhypic-O $\left.)\right] \cdot \mathrm{H}_{2} \mathrm{O}^{18}$ as well as the O,O-ligand through the carboxylate-O and the phenolate-O atoms as observed in the $\mathrm{V}^{\mathrm{IV}} \mathrm{O}$ mononuclear compound $\left[\mathrm{VO}\left(\text { Hhypic-N,O)(Hhypic-O, } \mathrm{O}^{\prime}\right)\left(\mathrm{H}_{2} \mathrm{O}\right)\right]^{30}$ and in the cyclic tetramer $\left[(\mathrm{VO})_{4}\left(\mu-\left(\text { hypic-N,O,O } \mathrm{O}^{\prime}, \mathrm{O}^{\prime \prime}\right)\right)_{4}\left(\mathrm{H}_{2} \mathrm{O}\right)_{4}\right]$ where hypic ${ }^{2-}$ acts as a bridging ligand (Scheme 2). ${ }^{30,31}$

CSD data for neutral mononuclear zinc(II) compounds with bidentate picolinato ligands show several different spatial arrangements for hexacoordinated structures. Isomer A (Scheme 3) with 19 compounds is the most frequent and was observed for example in trans-[ $\left.\mathrm{Zn}(\mathrm{pic})_{2}\left(\mathrm{H}_{2} \mathrm{O}\right)_{2}\right](\mathrm{Hpic}=\text { picolinic acid })^{32}$ and trans- $\left[\mathrm{Zn}(\mathrm{Hypic})_{2}\left(\mathrm{H}_{2} \mathrm{O}\right)_{2}\right]^{19}$ and also in 5, 10, and 11. Structure B with a cis arrangement was found in six entries where the neutral ligand L is imidazole, pyridine, 4-aminopyridine or

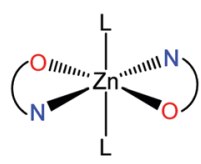

(A)

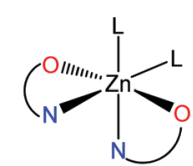

(B)

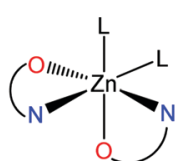

(C)

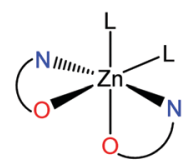

(D)

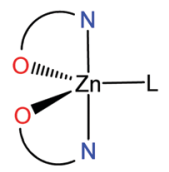

(E)

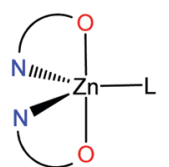

(F)
(G)

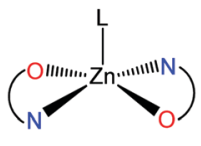

Scheme 3 Observed bis-chelated structures for $\mathrm{Zn}^{2+}$ species formed by $\mathrm{N}, \mathrm{O}$ a bidentate picolinato ligand and analogues in the presence of a neutral ligand $\mathrm{L}$. phenanthroline and was found also in 6-8 and $12 .{ }^{23,33}$ For each additional two cis spatial arrangements for the octahedral environment was reported only one example, cis- $\left[\mathrm{Zn}(\mathrm{pic})_{2}\left(\mathrm{H}_{2} \mathrm{O}\right)_{2}\right]^{34}$ possesses the structure $\mathrm{C}$ and $\left[\mathrm{Zn}(\text { bipyc })_{2}\left(\mathrm{H}_{2} \mathrm{O}\right)_{2}\right]^{35}\left(\mathrm{Hbipyc}=4,4^{\prime}-\right.$ bipyridyl-2-carboxylic acid) possesses the structure D. For comparison, the pentacoordinated arrangement is less frequent with only eight reported structures. Out of these, five complexes $\left[\mathrm{Zn}(6 \mathrm{Rpic})_{2}\left(\mathrm{H}_{2} \mathrm{O}\right)\right]$ (H6Rpic = 6-methylpicolinic acid and 6-ethylpicolinic acid), ${ }^{32,36}\left[\mathrm{Zn}(\mathrm{q} 2 \mathrm{c})_{2}\left(\mathrm{H}_{2} \mathrm{O}\right)\right]$ (Hq2c $=$ quinoline-2carboxylic acid), ${ }^{37}\left[\mathrm{Zn}(3 \mathrm{apic})_{2}\left(\mathrm{H}_{2} \mathrm{O}\right)\right]$ (H3apic = 3-aminopicolinic acid $)^{38}$ and $\left[\mathrm{Zn}(\mathrm{bp} 18 \mathrm{c} 6)_{2}\left(\mathrm{H}_{2} \mathrm{O}\right)\right]\left(\mathrm{H}_{2} \mathrm{bp} 18 \mathrm{c} 6=N, N^{\prime}\right.$-bis $[(6$-carboxy2-pyridyl)methyl]-4,13-diaza-18-crown-6) ${ }^{39}$ exhibit the trigonalbipyramidal geometry $\mathrm{E}$ with the nitrogen donor atoms in an axial position and one complex $\left[\mathrm{Zn}(\mathrm{Hpycc})_{2}\left(\mathrm{H}_{2} \mathrm{O}\right)\right]\left(\mathrm{H}_{2} \mathrm{pycc}=\right.$ pyridine-5-carboxylato-2-carboxylic acid $)^{40}$ exhibits the trigonalbipyramidal geometry $\mathrm{F}$ with the carboxylic oxygen atoms in an axial position. The square-pyramidal geometry $\mathrm{G}$ was reported only in two complexes $\left[\mathrm{Zn}(\text { bupyc) })_{2}\left(\mathrm{H}_{2} \mathrm{O}\right)\right]$ (Hbupyc $=$ 5-butylpyridine-2carboxylic acid $)^{41}$ and $\left[\mathrm{Zn}(\text { picCN })_{2}(4 a p y)\right]($ HpicCN $=5$-cyanopicolinic acid, 4apy $=4$-aminopyridine) ${ }^{23}$ In previously published zinc complexes with the 5 -cianopicolinato (picCN) organic carrier in the presence of the 4apy ligand in a $1: 2$ ratio the cis-octahedral complex $\left[\mathrm{Zn}(\text { picCN })_{2}(4 a p y)_{2}\right]$ was obtained from the apolar solvent system and the square-pyramidal complex $\left[\mathrm{Zn}(\text { picCN })_{2}\right.$ (4apy)] was obtained from methanol. ${ }^{23}$ On the other hand, the reaction of the starting compound [ $\left.\mathrm{Zn}(\mathrm{Hypic})_{2}\left(\mathrm{H}_{2} \mathrm{O}\right)_{2}\right]$ (9) with two equivalents of DMAP in methanol gave small amount of crystals $\mathbf{1 0}$ with methanol molecules bonded to metal center and the same reaction in chloroform/toluene/methanol solvent mixture gave complex $\mathbf{1 1}$ as the product. These findings show the rich structural diversity and an important influence of the solvent system.

\section{In vitro insulin-mimetic activity}

The inhibitory effects on free fatty acid (FFA) release from the isolated rat adipocytes treated with epinephrine were measured on selected vanadium and zinc complexes with sufficient solubility in water in order to determine the insulin-like activities. For these in vitro experiments seven vanadium and zinc complexes with 3,5-difluoropicolinato, 3-hydroxypicolinato and 4-(hydroxymethyl)picolinato ligands were found to have suitable solubility in water. Two of them were the vanadium(Iv) complexes $\left[\mathrm{VO}(\mathrm{picFF})_{2}\left(\mathrm{H}_{2} \mathrm{O}\right)\right]$ (1) and $\mathrm{Na}\left[\mathrm{VO}(\text { Hhypic })_{3}\right] \cdot \mathrm{H}_{2} \mathrm{O}$ (2) which were synthesized as described previously ${ }^{18}$ and two were their vanadium(V) analogues $(3,4)$. The zinc(II) complexes selected were 5, 9 and 13. The effects of the vanadium and zinc complexes on the FFA release compared with those of the inorganic compounds VS $\left(\mathrm{VOSO}_{4}\right)$ and $\mathrm{ZS}\left(\mathrm{ZnSO}_{4}\right)$ are summarized in Fig. 12 and 13, respectively. All the studied complexes show insulin-mimetic activity. Vanadium complexes 1-4 exhibit activities similar to $\mathrm{VOSO}_{4}$ with Hhypic complexes $(2,4)$ being more active than the picFF ones. According to previous findings ${ }^{13 a} \mathrm{~V}^{\mathrm{IV}} \mathrm{O}$ compounds generally exhibit higher activity than $\mathrm{V}^{\mathrm{V}} \mathrm{O}_{2}$ species and this observation can be attributed to the different redox behavior of the vanadium species, ${ }^{42}$ the different mechanism of cellular uptake ${ }^{43}$ or the different speciation in the cytosol, ${ }^{44}$ and it has been also proposed that 


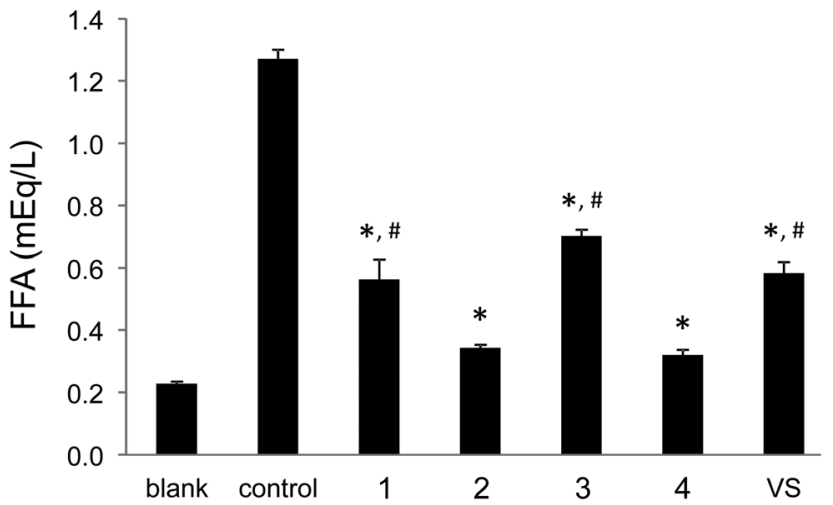

Fig. 12 Inhibitory effects of vanadium complexes (1-4) and $\mathrm{VOSO}_{4}$ (VS) on the free fatty acid release from isolated rat adipocytes treated with epinephrine. The blank represents cells only and the control represents cells plus $10 \mu \mathrm{M}$ epinephrine solution. Data are expressed as the means \pm SDs for three experiments at a $0.5 \mathrm{mM}$ concentration of the vanadium complex in water Significant differences were analyzed by one-way analysis of variance and Tukey test. *: $p<0.01$ vs. control, and \#: $p<0.01$ vs. compound 2 .

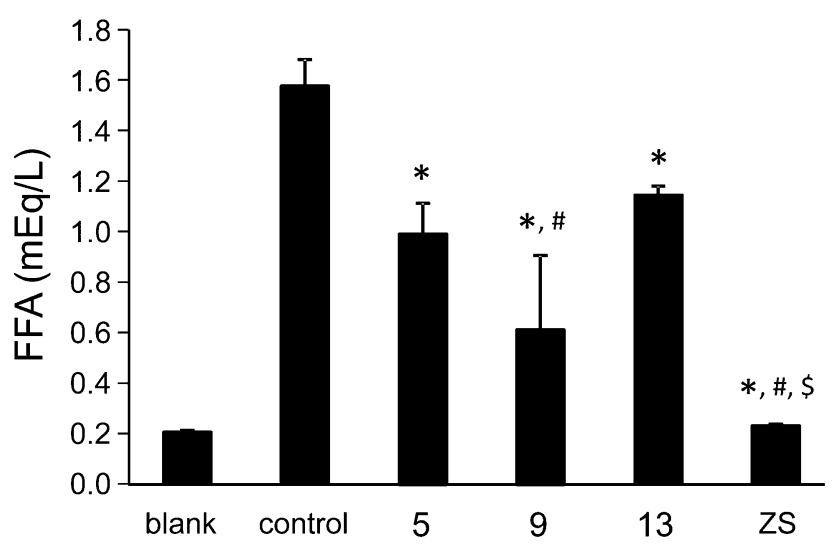

Fig. 13 Inhibitory effects of zinc complexes $(5,9,13)$ and $\mathrm{ZnSO}_{4}(\mathrm{ZS})$ on the free fatty acid release from isolated rat adipocytes treated with epinephrine. The blank represents cells only and the control represents cells plus $10 \mu \mathrm{M}$ epinephrine solution. Data are expressed as the means \pm SDs for three experiments at $0.5 \mathrm{mM}$ concentration of the zinc complex in water. Significant differences were analyzed by one-way analysis of variance and Tukey test. *: $p<0.01$ vs. control, \#: $p<0.01$ vs. compound 13, and $\$: p<0.01$ vs. compound 5 .

$\left[\mathrm{V}^{\mathrm{IV}} \mathrm{O}(\mathrm{OH})_{3}\right]^{-}$could be the active species. ${ }^{5,10}$ In our study the picFF complex with $\mathrm{V}^{\mathrm{IV}} \mathrm{O}$ indeed exhibits slightly higher activity than the $\mathrm{V}^{\mathrm{V}} \mathrm{O}_{2}$ complex, while in the Hhypic complexes the oxidation state of the metal center has no significant influence on the inhibition of FFA. Zinc complexes also exhibited some insulin-mimetic activity, with the Hhypic complex (9) being more active than the other two, however, the insulin-mimetic activity of these complexes did not show more potent activity than $\mathrm{ZnSO}_{4}$.

\section{Conclusion}

Two vanadium(v) compounds with 3,5-difluoropicolinato acid (HpicFF) and 3-hydroxypicolinato acid ( $\mathrm{H}_{2}$ hypic), four zinc(II) compounds with HpicFF in the presence of water, pyridine (py), 4-(dimethylamino)pyridine (DMAP), and 1,10-phenanthroline (phen) and two zinc(II) compounds with $\mathrm{H}_{2}$ hypic in the presence of DMAP and phen as well as a zinc(II) compound with $\mathrm{HpicCH}_{2} \mathrm{OH}$ have been prepared and characterized. The crystal structure of $\mathrm{NH}_{4}\left[\mathrm{VO}_{2}(\mathrm{picFF})_{2}\right] \cdot 1.6 \mathrm{H}_{2} \mathrm{O}\left(3 \cdot 1.6 \mathrm{H}_{2} \mathrm{O}\right)$ possesses a spatial arrangement with the carboxylate oxygen atoms in a mutual trans orientation although the carboxylate oxygen atoms in the prototypical complex $\mathrm{NH}_{4}\left[\mathrm{VO}_{2}(\mathrm{pic})_{2}\right]$ are positioned in a mutual cis orientation. The crystal structure of $\mathrm{NH}_{4}\left[\mathrm{VO}_{2}(\text { Hhypic })_{2}\right] \cdot \mathrm{H}_{2} \mathrm{O}\left(\mathbf{4} \cdot \mathrm{H}_{2} \mathrm{O}\right)$ represents the first crystallographic evidence for the formation of an isomer with the two pyridine nitrogen atoms in a mutual trans position although 3-hydroxypicolinic acid could ligate also as a bidentate $\mathrm{O}, \mathrm{O}-$ ligand through the carboxylate-O and phenolate-O atoms. In the crystal structures of zinc bis(3,5-difluoropicolinato) and bis(3-hydroxypicolinato) complexes $\left[\mathrm{Zn}(\mathrm{picFF})_{2}\left(\mathrm{H}_{2} \mathrm{O}\right)_{2}\right] \quad$ (5), $\left[\mathrm{Zn}(\mathrm{picFF})_{2}(\mathrm{py})_{2}\right] \cdot$ py $(6 \cdot \mathrm{py}),\left[\mathrm{Zn}(\mathrm{picFF})_{2}(\mathrm{DMAP})_{2}\right] \cdot 2 / 3 \mathrm{H}_{2} \mathrm{O}\left(7 \cdot 2 / 3 \mathrm{H}_{2} \mathrm{O}\right)$, $\left[\mathrm{Zn}(\mathrm{picFF})_{2}(\mathrm{phen})\right] \cdot 2 \mathrm{CHCl}_{3}\left(\mathbf{8} \cdot 2 \mathrm{CHCl}_{3}\right),\left[\mathrm{Zn}(\mathrm{Hhypic})_{2}(\mathrm{MeOH})_{2}\right](\mathbf{1 0})$, $\left[\mathrm{Zn}(\mathrm{Hhypic})_{2}(\mathrm{DMAP})\left(\mathrm{H}_{2} \mathrm{O}\right)\right]$ (11) and $\left[\mathrm{Zn}(\text { Hhypic })_{2}(\right.$ phen $\left.)\right](\mathbf{1 2})$ two different spatial arrangements were found with trans $(5,10$ and 11) and cis $(\mathbf{6}, 7, \mathbf{8}$ and 12) octahedral geometry. The presence of the DMAP ligand seems not to play a crucial role in the spatial arrangement since the geometry in $\mathbf{7}$ is cis and in $\mathbf{1 1}$ it is trans. Attempts were made to prepare the analogue of $\mathbf{1 1}$ with the py ligand for structural comparison with $\mathbf{6}$, however, we were not able to obtain crystals suitable for XRD analysis. As already observed for $\left[\mathrm{Zn}(\mathrm{picCN})_{2}(\mathrm{py})_{2}\right]$ also 6 loses all pyridine molecules on standing in air and is transformed to the water complex 5. The insulinmimetic activity of $\mathrm{V}^{\mathrm{IV}} \mathrm{O}(\mathbf{1}, \mathbf{2}), \mathrm{V}^{\mathrm{V}} \mathrm{O}_{2}(\mathbf{3}, \mathbf{4})$ and the $\mathrm{Zn}^{\mathrm{II}}$ complexes $(5,9$ and 13) was studied by an in vitro inhibition of the free fatty acid (FFA) release from isolated rat adipocytes treated with epinephrine. All selected metal complexes showed the insulinmimetic activity. Vanadium complexes 1-4 exhibit activities similar to $\mathrm{VOSO}_{4}$ with $\mathrm{H}_{2}$ hypic complexes being more active than the picFF ones. Zinc complexes also exhibited some insulin-mimetic activity, with the $\mathrm{H}_{2}$ hypic complex (9) being more active than the other two $(5,13)$.

\section{Conflicts of interest}

There are no conflicts of interest to declare.

\section{Acknowledgements}

The authors thank the Slovenian Research Agency for financial support (P1-0230-0175) as well as the EN-FIST Centre of Excellence, Slovenia for use of the Supernova diffractometer.

\section{References}

1 IDF Diabetes Atlas, International Diabetes Federation, 7th edn, 2015.

2 L. Guariguata, D. R. Whiting, I. Hambleton, J. Beagley, U. Linnenkamp and J. E. Shaw, Diabetes Res. Clin. Pract., 2014, 103, 137-149. 
3 Y. Yoshikawa and H. Yasui, Curr. Top. Med. Chem., 2012, 12, 210-218.

4 G. Vardatsikos, N. R. Pandey and A. K. Srivastava, J. Inorg. Biochem., 2013, 120, 8-17.

5 (a) D. C. Crans, J. J. Smee, E. Gaidamauskas and L. Yang, Chem. Rev., 2004, 104, 849-902; (b) D. Rehder, Future Med. Chem., 2016, 8, 325-338; (c) J. Costa Pessoa, E. Garribba, M. F. A. Santos and T. Santos-Silva, Coord. Chem. Rev., 2015, 301-302, 49-86.

6 (a) E. Mrkalić, A. Zianna, G. Psomas, M. Gdaniec, A. Czapik, E. Coutouli-Argyropoulou and M. Lalia-Kantouri, J. Inorg. Biochem., 2014, 134, 66-75; (b) A. Zianna, G. Psomas, A. Hatzidimitriou, E. Coutouli-Argyropoulou and M. LaliaKantouri, J. Inorg. Biochem., 2013, 127, 116-126; (c) A. Tarushi, E. Polatoglou, J. Kljun, I. Turel, G. Psomas and D. P. Kessissoglou, Dalton Trans., 2011, 40, 9461-9473.

7 (a) A. Tarushi, X. Totta, A. Papadopoulos, J. Kljun, I. Turel, D. P. Kessissoglou and G. Psomas, Eur. J. Med. Chem., 2014, 74, 187-198; (b) A. Tarushi, Z. Karaflou, J. Kljun, I. Turel, G. Psomas, A. N. Papadopoulos and D. P. Kessissoglou, J. Inorg. Biochem., 2013, 128, 85-96.

8 A. Tarushi, K. Lafazanis, J. Kljun, I. Turel, A. A. Pantazaki, G. Psomas and D. P. Kessissoglou, J. Inorg. Biochem., 2013, 121, 53-65.

9 H. Kozlowski, M. Luczkowski, M. Remelli and D. Valensin, Coord. Chem. Rev., 2012, 256, 2129-2141.

10 (a) D. Rehder, Future Med. Chem., 2012, 4, 1823-1837; (b) D. Rehder, Dalton Trans., 2013, 42, 11749-11761; (c) J. Costa Pessoa, E. Garribba, M. F. A. Santos and T. Santos-Silva, Coord. Chem. Rev., 2015, 301-302, 49-86; (d) D. Gambino, Coord. Chem. Rev., 2011, 255, 2193-2203; (e) C. Rozzo, D. Sanna, E. Garribba, M. Serra, A. Cantara, G. Palmieri and M. Pisano, J. Inorg. Biochem., 2017, 174, 14-24; $(f)$ D. Sanna, V. Ugone, A. Fadda, G. Micera and E. Garribba, J. Inorg. Biochem., 2016, 161, 18-26.

11 B. M. Lyonett and E. Martin, La Press Med., 1899, 32, 191-192.

12 Y. Shechter, I. Goldwaser, M. Mironchik, M. Fridkin and D. Gefel, Coord. Chem. Rev., 2003, 237, 3-11.

13 (a) D. Rehder, J. C. Pessoa, C. F. Geraldes, M. M. Castro, T. Kabanos, T. Kiss, B. Meier, G. Micera, L. Pettersson, M. Rangel, A. Salifoglou, I. Turel and D. Wang, J. Biol. Inorg. Chem., 2002, 7, 384-396; (b) K. H. Thompson and C. Orvig, J. Inorg. Biochem., 2006, 100, 1925-1935; (c) K. H. Thompson, J. Lichter, C. LeBel, M. C. Scaife, J. H. McNeill and C. Orvig, J. Inorg. Biochem., 2009, 103, 554-558; (d) A. Levina and P. A. Lay, Dalton Trans., 2011, 40, 11675-11686; (e) J. Costa Pessoa, S. Etcheverry and D. Gambino, Coord. Chem. Rev., 2015, 301-302, 24-48; $(f)$ K. D. Mjos and C. Orvig, Chem. Rev., 2014, 114, 4540-4563.

14 (a) H. Sakurai, Y. Yoshikawa and H. Yasui, Chem. Soc. Rev., 2008, 37, 2383-2392; (b) H. Sakurai, Y. Kojima, Y. Yoshikawa, K. Kawabe and H. Yasui, Coord. Chem. Rev., 2002, 226, 187-198.

15 (a) R. Saito, M. Tamura, S. Kawano, Y. Yoshikawa, A. Kato, K. Sasaki and H. Yasui, New J. Chem., 2017, 41, 5572-5581; (b) Y. Naito, Y. Yoshikawa, K. Masuda and H. Yasui,
J. Biol. Inorg. Chem., 2016, 21, 537-548; (c) J. Pelletier, N. Domingues, M. M. C. A. Castro and C.-G. Östenson, J. Inorg. Biochem., 2016, 154, 29-34; (d) B. Fernández, A. Gómez-Vílchez, C. Sánchez-González, J. Bayón, E. San Sebastián, S. Gómez-Ruiz, C. López-Chaves, P. Aranda, J. Llopis and A. Rodríguez-Diéguez, New J. Chem., 2016, 40, 5387-5393; (e) D. Briones, B. Fernández, A. J. Calahorro, D. Fairen-Jimenez, R. Sanz, F. Martínez, G. Orcajo, E. San Sebastián, J. M. Seco, C. Sánchez González, J. Llopis and A. Rodríguez-Diéguez, Cryst. Growth Des., 2016, 16, 537-540; $(f)$ N. Wang, Z. Wang, X. Niu and X. Yang, J. Inorg. Biochem., 2015, 152, 104-113; ( $g$ ) T. Moroki, Y. Yoshikawa, K. Yoshizawa, A. Tsubura and H. Yasui, Metallomics, 2014, 6, 1632-1638; (h) M. E. López-Viseras, B. Fernández, S. Hilfiker, C. S. González, J. L. González, A. J. Calahorro, E. Colacio and A. Rodríguez-Diéguez, J. Inorg. Biochem., 2014, 131, 64-67; (i) N. Domingues, J. Pelletier, C.-G. Ostenson and M. M. C. A. Castro, J. Inorg. Biochem., 2014, 131, 115-122; (j) Z.-Q. Han, S. Han and Y. Wang, Acta Chim. Slov., 2016, 63, 200-203; (k) J.-X. Lei, J. Wang, Y. Huo and Z. You, Acta Chim. Slov., 2016, 63, 670-677.

16 (a) Y. Adachi, J. Yoshida, Y. Kodera, A. Katoh, J. Takada and H. Sakurai, J. Med. Chem., 2006, 49, 3251-3256; (b) M. Hiromura, Y. Adachi, M. Machida, M. Hattori and H. Sakurai, Metallomics, 2009, 1, 92-100; (c) Y. Adachi, J. Yoshida, Y. Kodera and H. Sakurai, Chem. Lett., 2005, 34, 656-657; (d) Y. Yoshikawa, Y. Adachi and H. Sakurai, Life Sci., 2007, 80, 759-766.

17 (a) M. Munekane, S. Motomura, S. Kamino, M. Ueda, H. Haba, Y. Yoshikawa, H. Yasui, M. Hiromura and S. Enomoto, Biochem. Biophys. Rep., 2016, 5, 211-215; (b) S. Fujimoto, H. Yasui and Y. Yoshikawa, J. Inorg. Biochem., 2013, 121, 10-15; (c) M. Munekane, M. Ueda, S. Motomura, S. Kamino, H. Haba, Y. Yoshikawa, H. Yasui and S. Enomoto, Biol. Pharm. Bull., 2017, 40, 510-515.

18 T. Koleša-Dobravc, E. Lodyga-Chruscinska, M. Symonowicz, D. Sanna, A. Meden, F. Perdih and E. Garribba, Inorg. Chem., 2014, 53, 7960-7976.

19 (a) C. Sun, X. Zheng and L. Jin, J. Mol. Struct., 2003, 646, 201-210; (b) V. B. Di Marco, A. Tapparo, A. Dolmella and G. G. Bombi, Inorg. Chim. Acta, 2004, 357, 135-142.

20 (a) Z. Otwinowski and W. Minor, Methods Enzymol., 1997, 276, 307-326; (b) CrysAlis PRO, Agilent Technologies, Yarnton, England, 2013.

21 (a) G. M. Sheldrick, Acta Crystallogr., 2015, C71, 3-8; (b) A. Altomare, M. C. Burla, M. Camalli, G. L. Cascarano, C. Giacovazzo, A. Guagliardi, A. G. G. Moliterni, G. Polidori and R. Spagna, J. Appl. Crystallogr., 1999, 32, 115-119.

22 M. Nakai, H. Watanabe, C. Fujiwara, H. Kakegawa, T. Satoh, J. Takada, R. Matsushita and H. Sakurai, Biol. Pharm. Bull., 1995, 18, 719-725.

23 T. Koleša-Dobravc, K. Maejima, Y. Yoshikawa, A. Meden, H. Yasui and F. Perdih, New J. Chem., 2017, 41, 735-746.

24 K. Nakamoto, Infrared and Raman Spectra of Inorganic and Coordination Compounds, Wiley, New York, 4th edn, 1986.

25 (a) K. A. Doucette, K. N. Hassell and D. C. Crans, J. Inorg. Biochem., 2016, 165, 56-70; (b) T. Jakusch, J. Costa Pessoa 
and T. Kiss, Coord. Chem. Rev., 2011, 255, 2218-2226; (c) M. F. A. Santos, I. Correia, A. R. Oliveira, E. Garribba, J. Costa Pessoa and T. Santos-Silva, Eur. J. Inorg. Chem., 2014, 3293-3297; (d) S. Mehtab, G. Gonçalves, S. Roy, A. I. Tomaz, T. Santos-Silva, M. F. A. Santos, M. J. Romão, T. Jakusch, T. Kiss and J. C. Pessoa, J. Inorg. Biochem., 2013, 121, 187-195; (e) G. Gonçalves, I. Tomaz, I. Correia, L. F. Veiros, M. M. C. A. Castro, F. Avecilla, L. Palacio, M. Maestro, T. Kiss, T. Jakusch, M. H. V. Garcia and J. C. Pessoa, Dalton Trans., 2013, 42, 11841-11861; $(f)$ D. Sanna, V. Ugone, M. Serra and E. Garribba, J. Inorg. Biochem., 2017, 173, 52-65; (g) D. Sanna, G. Sciortino, V. Ugone, G. Micera and E. Garribba, Inorg. Chem., 2016, 55, 7373-7387; (h) S. P. Dash, S. Majumder, A. Banerjee, M. Fernanda, N. N. Carvalho, P. Adão, J. Costa Pessoa, K. Brzezinski, E. Garribba, H. Reuter and R. Dinda, Inorg. Chem., 2016, 55, 1165-1182; (i) D. Sanna, M. Serra, G. Micera and E. Garribba, Inorg. Chem., 2014, 53, 1449-1464; ( $j$ ) D. Sanna, G. Micera and E. Garribba, Inorg. Chem., 2013, 52, 11975-11985; (k) E. Lodyga-Chruscinska, G. Micera and E. Garribba, Inorg. Chem., 2011, 50, 883-899; (l) D. Sanna, G. Micera and E. Garribba, Inorg. Chem., 2011, 50, 3717-3728; $(m)$ D. Sanna, G. Micera and E. Garribba, Inorg. Chem., 2009, 48, 5747-5757.

26 (a) T. Koleša-Dobravc, A. Meden and F. Perdih, New J. Chem., 2015, 39, 4265-4277; (b) T. Koleša-Dobravc, A. Meden and F. Perdih, Acta Chim. Slov., 2015, 62, 261-271; (c) T. KolešaDobravc, A. Meden and F. Perdih, Monatsh. Chem., 2014, 145, 1263-1275.

27 J. Gätjens, B. Meier, T. Kiss, E. M. Nagy, P. Buglyó, H. Sakurai, K. Kawabe and D. Rehder, Chem. - Eur. J., 2003, 9, 4924-4935.

28 G. Süss-Fink, S. Stanislas, G. B. Shul'pin, G. V. Nizova, H. Stoeckli-Evans, A. Neels, C. Bobillier and S. Claude, J. Chem. Soc., Dalton Trans., 1999, 3169-3175.

29 M. Melchior, K. H. Thompson, J. M. Jong, S. J. Rettig, E. Shuter, V. G. Yuen, Y. Zhou, J. H. McNeill and C. Orvig, Inorg. Chem., 1999, 38, 2288-2293.

30 (a) S. Yano, M. Nakai, F. Sekiguchi, M. Obata, M. Kato, M. Shiro, I. Kinoshita, M. Mikuriya, H. Sakurai and C. Orvig,
Chem. Lett., 2002, 916-917; (b) M. Nakai, M. Obata, F. Sekiguchi, M. Kato, M. Shiro, A. Ichimura, I. Kinoshita, M. Mikuriya, T. Inohara, K. Kawabe, H. Sakurai, C. Orvig and S. Yano, J. Inorg. Biochem., 2004, 98, 105-112.

31 E. Kiss, A. Bényei and T. Kiss, Polyhedron, 2003, 22, 27-33. 32 Y. Yoshikawa, E. Ueda, K. Kawabe, H. Miyake, T. Takino, H. Sakurai and Y. Kojima, J. Biol. Inorg. Chem., 2002, 7, 68-73.

33 (a) D. Dobrzyńska, T. Lis and L. B. Jerzykiewicz, Inorg. Chem. Commun., 2005, 8, 1090-1093; (b) H.-L. Seng, S.-T. Von, K.-W. Tan, M. J. Maah, S.-W. Ng, R. N. Z. R. A. Rahman, I. Caracelli and C.-H. Ng, BioMetals, 2009, 23, 99-118; (c) J.-C. Daran, P. Lemoine and B. Viossat, Acta Crystallogr., 2002, C58, $\mathrm{m} 210-\mathrm{m} 212$.

34 L. Croitor, D. Chisca, E. B. Coropceanu and M. S. Fonari, Acta Crystallogr., Sect. E: Struct. Rep. Online, 2013, 69, m454.

35 C.-L. Chen, J. M. Ellsworth, A. M. Goforth, M. D. Smith, C.-Y. Su and H.-C. zur Loye, Dalton Trans., 2006, 5278-5286. 36 Y. Kojima, Y. Yoshikawa, E. Ueda, N. Kishimoto, M. Tadokoro and H. Sakurai, Bull. Chem. Soc. Jpn., 2005, 78, 451-455.

37 N. Okabe and Y. Muranishi, Acta Crystallogr., Sect. E: Struct. Rep. Online, 2003, 59, m244-m246.

38 D. Wang, S.-M. Li, Y.-F. Li, X.-J. Zheng and L.-P. Jin, Dalton Trans., 2016, 45, 8316-8319.

39 R. Ferreirós-Martínez, D. Esteban-Gómez, É. Tóth, A. de Blas, C. Platas-Iglesias and T. Rodríguez-Blas, Inorg. Chem., 2011, 50, 3772-3784.

40 Y.-C. Liang, M.-C. Hong, R. Cao and J.-B. Weng, Chin. J. Struct. Chem., 2001, 20, 455-458.

41 Y.-W. Tao and Y. Wang, Acta Crystallogr., Sect. E: Struct. Rep. Online, 2011, 67, m908.

42 Y. Yoshikawa, H. Sakurai, D. C. Crans, G. Micera and E. Garribba, Dalton Trans., 2014, 43, 6965-6972.

43 X. Yang, K. Wang, J. Lu and D. C. Crans, Coord. Chem. Rev., 2003, 237, 103-111.

44 A. Levina, A. I. McLeod, S. J. Gasparini, A. Nguyen, W. G. M. De Silva, J. B. Aitken, H. H. Harris, C. Glover, B. Johannessen and P. A. Lay, Inorg. Chem., 2015, 54, 7753-7766. 